Review

\title{
Biotechnological Potential of LSD1, EDS1, and PAD4 in the Improvement of Crops and Industrial Plants
}

\author{
Maciej Jerzy Bernacki 1,2, Weronika Czarnocka 1,3®i), Magdalena Szechyńska-Hebda ${ }^{4,5}$, \\ Ron Mittler ${ }^{2}$ and Stanisław Karpiński ${ }^{1, *}$ \\ 1 Department of Plant Genetics, Breeding and Biotechnology, Faculty of Horticulture, Biotechnology and \\ Landscape Architecture, Warsaw University of Life Sciences, Nowoursynowska Street 159, \\ 02-776 Warsaw, Poland \\ 2 The Division of Plant Sciences, College of Agriculture, Food and Natural Resources, Christopher S. Bond \\ Life Sciences Center, University of Missouri, Columbia, MO 65201, USA \\ 3 Department of Botany, Faculty of Agriculture and Biology, Warsaw University of Life Sciences, \\ Nowoursynowska Street 159, 02-776 Warsaw, Poland \\ 4 The Franciszek Górski Institute of Plant Physiology, Polish Academy of Sciences, Niezapominajek Street 21, \\ 30-239 Cracow, Poland \\ 5 The Plant Breeding and Acclimatization Institute - National Research Institute, \\ 05-870 Błonie, Radzików, Poland \\ * Correspondence: stanislaw_karpinski@sggw.pl
}

Received: 24 July 2019; Accepted: 14 August 2019; Published: 16 August 2019

check for updates

\begin{abstract}
Lesion Simulating Disease 1 (LSD1), Enhanced Disease Susceptibility (EDS1) and Phytoalexin Deficient 4 (PAD4) were discovered a quarter century ago as regulators of programmed cell death and biotic stress responses in Arabidopsis thaliana. Recent studies have demonstrated that these proteins are also required for acclimation responses to various abiotic stresses, such as high light, UV radiation, drought and cold, and that their function is mediated through secondary messengers, such as salicylic acid (SA), reactive oxygen species (ROS), ethylene (ET) and other signaling molecules. Furthermore, LSD1, EDS1 and PAD4 were recently shown to be involved in the modification of cell walls, and the regulation of seed yield, biomass production and water use efficiency. The function of these proteins was not only demonstrated in model plants, such as Arabidopsis thaliana or Nicotiana benthamiana, but also in the woody plant Populus tremula $x$ tremuloides. In addition, orthologs of LSD1, EDS1, and PAD4 were found in other plant species, including different crop species. In this review, we focus on specific LSD1, EDS1 and PAD4 features that make them potentially important for agricultural and industrial use.
\end{abstract}

Keywords: Biomass; LSD1; EDS1; PAD4; seed yield; WUE

\section{Introduction}

Enhancing agricultural production is one of the greatest challenges of the 21st century. This goal should be achieved with the least possible use of pesticides and fertilizers, that despite their benefits, can contaminate groundwater and the surrounding soils, and are highly hazardous to both humans and the environment [1-5]. Moreover, along with the need for increasing yield quantity and quality, a major challenge for modern agriculture is the reduction of water consumption, as a high proportion of available freshwater from rivers and groundwater goes into crop irrigation, and the availability of these waters is rapidly decreasing, due to global climatic changes and dwindling water resources [6-9].

For three decades, genetic engineering has made it possible to develop genetically-modified (GM) crops and trees designed for yield improvement and efficient agriculture management [10-13]. GM crops were introduced into commercial use in the USA in 1994 [14]. To date, soybean, cotton 
and corn are the most common genetically-modified crops [15]. Nearly $93 \%$ of soybean and $88 \%$ of corn crops in the US are genetically modified, according to the United States Food and Drug Administration (FDA). Many GM crops have been engineered to resist certain herbicides, e.g., the majority of currently-cultivated GM plants are resistant to the herbicide Roundup (Monsanto/Bayer, Leverkeusen, Germany) [11,16]. These make it possible to use soil-protective and no-till cultivation methods, significantly reducing pesticide usage. Another successfully used strategy is the cultivation of insect-resistant plants containing the bacterial gene encoding the Bt toxin (Cry protein), that is poisonous for noxious insects [17]. Almost one-third of all genetically-engineered crops have combined herbicide tolerance and insect resistance (stacked genes).

Thus far, crops with genetically-modified genes enhancing resistance to abiotic stresses have not been cultivated on a large scale. This situation results from the fact that most abiotic stress tolerance traits are controlled by multiple genes present at multiple loci $[18,19]$. However, genome-editing tools, particularly the CRISPR/Cas9 technology, provide the premise for multiple and efficient target modifications of the plant genome [20]. Additionally, faster and cheaper sequencing techniques, such as Next-Generation sequencing of crop genomes, enables the identification of multiple genes involved in responses to abiotic stresses [21]. The coupling of these techniques with traditional and advanced breeding practices could revolutionize plant biotechnology in the coming years.

In this review, we discuss the benefits of modification to genes involved in the regulation of programmed cell death (PCD) and acclimation to biotic and/or abiotic stresses, with a focus on Lesion Simulating Disease 1 (LSD1), Enhanced Disease Susceptibility (EDS1) and Phytoalexin Deficient 4 (PAD4) that have orthologs in many plant species, including Arabidopsis thaliana, Nicotiana betnhamiana, Populus tremula $x$ tremuloides, Oryza sativa [22,23], Triticum aestivum [24,25], Gossypium barbadense [26,27], Vitis vinifera [28,29], Lycopersicon esculentum [30,31], Pisum sativum [32] and others. Although the potential benefits of $l s d 1$, eds1 and pad4 mutants over wild type plants have been previously addressed [33-35], here we discuss new discoveries related to the applications of LSD1, EDS1 and PAD4 in improving crops and woody plants for different biotechnological applications.

\section{LSD1, EDS1, and PAD4 Play a Crucial Role in the Response to Both Biotic and Abiotic Stresses}

LSD1 is known as a negative regulator of PCD, since it was found that the Arabidopsis thaliana lsd1 mutant exhibits an inability to stop cell death once it was activated [36]. Under unfavorable conditions, the phenotype of $l s d 1$ is manifested by a fast spread of lesions i.e., a runaway cell death (RCD). The RCD phenotype is induced by a superoxide anion $\left(\mathrm{O}_{2}^{-}\right)$and $\mathrm{H}_{2} \mathrm{O}_{2}$, which are excessively produced in an $l s d 1$ mutant [37-44]. Hormones important for plant defense i.e., salicylic acid (SA) and ethylene (ET) are also over-accumulated in $l s d 1[35,40,42,44,45]$. It was found that in the NahG/lsd1 plants that are unable to accumulate SA because of the NahG bacterial gene, encoding salicylate hydroxylase that converts SA to catechol, cell death was suppressed [46]. Similarly, a mutation in the ET receptor AtEIN2, introduced into the $l s d 1$ background, mitigated the cell death phenotype in $1 s d 1 / e i n 2$ double mutants [47]. These results suggest that LSD1-dependent cell death is associated not only with ROS, but also requires SA and ET function.

LSD1 plays an important role in the response and acclimation of plants to a broad range of stresses such as drought [35,48], UV-C radiation [44,46], cold stress [49], excess light [41], root hypoxia [42] and pathogens [43]. Interestingly, the $l s d 1$ phenotype shows conditional dependence on environmental conditions, and the morphology and seed yield of the mutant does not differ from the wild type when plants are grown under field conditions $[35,45]$. LSD1 acts as a negative regulator of EDS1 and PAD4 $[43-45,50,51]$ in PCD, and double mutants $e d s 1 / / s d 1$ and $p a d 4 / / s d 1$ demonstrate a reverted RCD phenotype, even under stress conditions [44,45].

EDS1 and PAD4 proteins function in resistance $(R)$ gene-mediated and basal disease resistance, and can physically interact with each other [52,53]. Both EDS1 and PAD4 show sequence homology to eukaryotic acyl lipases [54,55]. The complexes of EDS1 and PAD4 regulate PAMP-triggered immunity (PTI) as well as Toll-interleukin-1 receptor-nucleotide binding-leucine-rich repeat (TIR-NB-LRR) 
protein-mediated signaling in response to pathogens [56-58]. The EDS1-PAD4 complex is also required for the accumulation of SA and systemic-acquired resistance (SAR) [52]. Mutations in AtEDS1 and AtPAD4 result in impaired SA, ET and ROS homeostasis, disrupted acclimatory responses and cell death signaling $[38,42,50,51,54]$. However, the role of EDS1 in promoting cell death under biotic and abiotic stresses appears superior to PAD4, and a mutation in AtEDS1 reverses the lsd1 mutant cell death phenotype stronger than the mutation in AtPAD4 [43,45]. It was found that LSD1, EDS1 and PAD4 are involved in lysigenous aerenchyma formation [42]. Aerenchyma formation is an acclimation response that allows plants to survive a low availability of oxygen in the soil, for example during flooding [59]. This process is under ROS and ET control, and it was found that in eds1 and pad4 mutants with lower ET and ROS content, the percent of the secondary xylem core was smaller than in the $l s d 1$ mutant with higher ET and ROS content [42]. Numerous studies demonstrate that LSD1, EDS1 and PAD4 form a specific hub that regulates cell death and acclimation responses to both, biotic and abiotic stresses $[28,41-44,46,50,51]$.

\section{LSD1, EDS1 and PAD4 Molecular Properties}

The LSD1 protein possesses three zinc (Zn)-finger domains, which enable DNA or protein binding $[51,60,61]$. The Zn-finger motif in LSD1 contains the conserved consensus sequence: CxxCRxxLMYxxGASxVxCxxC that belongs to the C2C2 class [62]. In Arabidopsis thaliana, LSD1 was found in both the nucleus and cytoplasm [50]. However, another study on Pisum sativum showed only a nuclear localization of LSD1 [32]. So far LSD1 has been found to interact directly or indirectly with 33 proteins [50,63-69], acting as a scaffold protein. Importantly, these interactions depend upon the cell's oxidative status [50]. Moreover, it was shown that LSD1 can act as a transcriptional regulator [50]. Significant changes in the transcriptome of the $l s d 1$ mutant grown under field conditions were found in comparison to the laboratory conditions [35], underlining the conditional-dependent role of LSD1.

Recently it was shown that LSD1 interacts directly with EDS1 [50], while EDS1 forms hetero-dimers with PAD4 [53]. EDS1 is mostly present in the cytoplasm, whereas EDS1-PAD4 and EDS1-LSD1 complexes appear in the nucleus [70]. This suggests dynamic interactions between EDS1 and its signaling partners in the plant cell $[50,52,53]$. Co-interactions of these proteins appear to be important for their cellular function [53,71]. Moreover, EDS1 interacts with seven other proteins including AT3G48080, considered to be a defense response protein [70], Response to Low Sulfur 1 (LSU1) [72], Recognition of Peronospora Parasitica 8 (RPP8) [73], Resistant to Pseudomonas syringae 4 (RPS4) [74], Ribsomal Protein S6 (RPS6) [75], Suppressor OF NPR1-1 (SCN1) [76], and Suppressor OF RPS4-RLD 1 (SRFR1) [77], while PAD4 has been found to interact only with AT3G48080 [71].

\section{The LSD1, EDS1, and PAD4 Regulatory Hub Links Plastoquinone, Salicylic acid, Ethylene, and ROS Signaling in Arabidopsis thaliana}

Stress factors, such as high light, UV radiation and high temperature have an influence on the quantum-redox status of the photosynthetic electron transport chain (ETC) components [78], and thus on ROS production and the glutathione/ascorbate redox status. The resulting changes in redox status affect hormone levels (including SA), ion and sugars signal transduction pathways $[79,80]$. As a feedback, these signals can lead to stomata closure, induce photorespiration, and trigger the overproduction of cell-death-signaling molecules, e.g., ROS and ET [48,79-86]. Importantly, ROS, ET, and SA signaling during cell death are under the control of LSD1, EDS1 and PAD4 $[35,51,53,87]$.

The $l s d 1$ mutant exhibits lower stomatal conductance, lower catalase (CAT) activity, and higher $\mathrm{H}_{2} \mathrm{O}_{2}$ content, even under control conditions of short-day and low light $[35,46]$. In response to high light or long-day conditions, $l s d 1$ over-accumulates $\mathrm{H}_{2} \mathrm{O}_{2}$, ET and SA, that induce RCD [41,42].

It was found that a mutation in the Chrloroplast Signal Recognition Particle 43 (AtCAO) gene rescues the $l s d 1$ phenotype. The $c a o / l s d 1$ double mutant absorbs fewer photons due to smaller photosystem II antennas size and higher NPQ, and this leads to an inhibition of RCD in response to excess light, compared to the $l s d 1$ single mutant [41]. Therefore, the RCD phenotype of $l s d 1$ is linked to the amount 
of absorbed light and redox status of plastoquinone (PQ) [51]. lsd1 also exhibits an RCD phenotype in response to UV stress [44], and it is known that UV irradiation affects the photosynthetic apparatus and redox status of the PQ pool $[88,89]$. LSD1 conformation and its activity are controlled by changes in the PQ pool [64], and it was hypothesized that under stress conditions, changes in the activity of LSD1 can reduce the activity of SOD and CAT proteins, and downregulate PR1 gene expression [51] (Figure 1). Under non-stress laboratory condition, eds1 and pad4 mutants accumulate less $\mathrm{H}_{2} \mathrm{O}_{2}$ than wild type plants [45], while double $e d s 1 / l s d 1$ and pad4/lsd1 exhibit similar [35] or lower [41] $\mathrm{H}_{2} \mathrm{O}_{2}$ level than wild type.

A

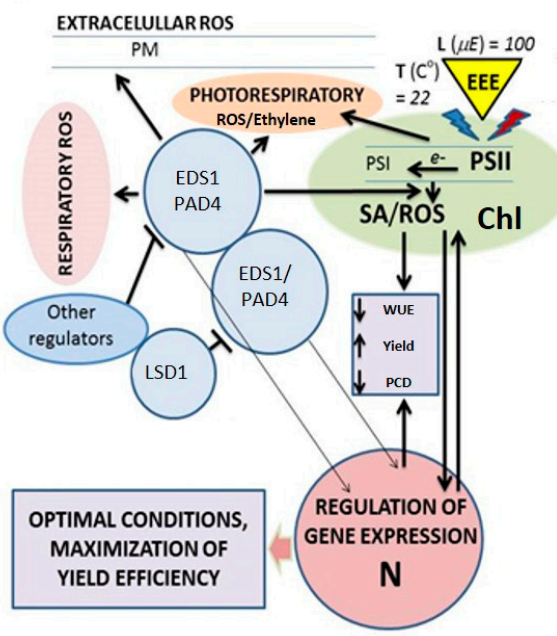

B

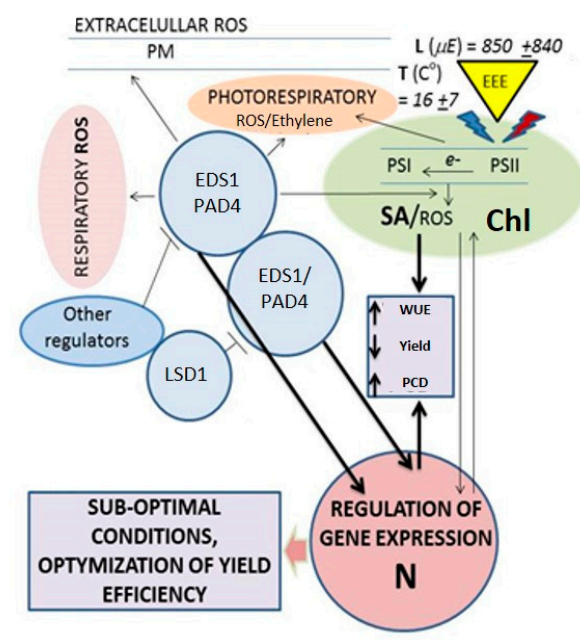

Figure 1. Proposed models of regulation and integration of seed yield, maximal photosynthetic efficiency, reactive oxygen species (ROS)/hormonal cellular homeostasis and water use efficiency by LESION SIMULATING DISEASE 1 (LSD1)/ENHANCED DISEASE SUSCEPTIBILITY 1 (EDS1)/PHYTOALEXIN DEFICIENT 4 (PAD4) in Arabidopsis. LSD1/EDS1/PAD4 is proposed to function as a regulatory hub in laboratory (A) and field (B) conditions. Bold lines-strong regulation, thin lines-weak regulation. WUE-water use efficiency, Yield—seed yield. Average light intensity ( $\mu \mathrm{mol}$ of photons $\mathrm{m}^{-2} \mathrm{~s}^{-1}$ ) and temperature $\left({ }^{\circ} \mathrm{C}\right)$ are given on the triangle borders that symbolize the capacity of the photosystems to absorb excess light energy (EEE). Chloroplast (Chl), nucleus (N), photosystem II and I (PSII and PSI), plasma membrane (PM), reactive oxygen species (ROS) and salicylic acid (SA).

Arabidopsis thaliana EDS1 and PAD4 form a regulatory hub, influencing the accumulation of SA [45,90]. Moreover, SA induces stomatal closure [91], which leads to photoinhibition [92-94]. Both inhibition of the antioxidant system and photoinhibition cause higher ROS accumulation [78,95-98]. It was found that $e d s 1$ and pad 4 mutants accumulate less SA than the wild type during biotic stress, while there is no difference in SA accumulation in plants overexpressing EDS1 or PAD4 [90]. Importantly, Arabidopsis plants overexpressing both EDS1 and PAD4 accumulate significantly more SA than wild type in response to biotic stress [87].

\section{Involvement of Salicylic Acid, Ethylene, and ROS in Plant Productivity}

LSD1, EDS1 and PAD4 can regulate SA, ET and ROS metabolism during systemic acquired acclimation [41,42] and systemic acquired resistance [43].

High foliar SA and $\mathrm{H}_{2} \mathrm{O}_{2}$ levels were found in the lsd1 mutant under both control and stress conditions. EDS1 and PAD4 mediate the ROS-derived signal leading to RCD in the lsd1 mutant [35,42]. LSD1 is also required for the SA-dependent induction of the antioxidant enzyme copper-zinc superoxide dismutase (Cu-Zn SOD) and potentially other antioxidant genes [33,41,44].

A ROS level exceeding the capability of the plant cell to mount an effective antioxidant response is harmful and could damage DNA, RNA, proteins and membranes, and in extreme cases, cause plant 
death $[81,98]$. However, $\mathrm{H}_{2} \mathrm{O}_{2}$ and $\mathrm{O}_{2}{ }^{-}$and their derivatives are also natural by-products of cellular metabolism, and are involved in a broad range of plant physiological and biochemical processes i.e., signaling, defense response and photosynthesis regulation during the entire plant lifespan [98-100]. Reactive Oxygen Species (ROS) do lead to growth inhibition and lower plant productivity during biotic and abiotic stress. Therefore, deregulation of genes involved in ROS metabolism or signaling (inclulding LSD1, EDS1 and PAD4) also affects plant growth and development [44,45,101-103].

Similarly, high levels of SA that accumulate during plant responses to environmental stresses are close to phytotoxicity, and could reduce plant growth or induce cell death [104-106]. However, through a complex signaling network, SA plays an important role in seed germination, root initiation, floral induction and thermogenesis [107-109]. SA is a negative regulator of auxins, and interferes with auxin-mediated responses [108,109]. In support of this link, SA-accumulating dwarf mutants such as cpr5, cpr6, and snc1 were shown to contain lower endogenous levels of free IAA and reduced sensitivity to auxins, compared with wild-type plants [110]. Moreover, the effects of the cpr1 and cpr6 mutations on SA-related gene expression were dependent upon PAD4 function, while SA accumulation in the lesion-mimic mutant cpr5 was partially PAD4-independent, and in other dwarf mutants, such as $d n d 1$ and $d n d 2$, it was completely PAD4-independent [111]. The significance of SA in plant growth is also demonstrated by the fact that the expression of bacterial NahG, which decomposes SA to katehol, in $l s d 1$ or acd6 (Accelerated Cell Death 6) backgrounds reverts their dwarf phenotypes [46,112]. Recent studies on Arabidopsis thaliana have also shown that SA content in plant tissues is strongly correlated with seed yield [45]. Accordingly, mutations in genes encoding positive regulators of SA signaling, EDS1 and PAD4, revert impaired growth and seed yield in the $l s d 1$ mutant $[35,45]$. Further, the EDS1-PAD4 complex is required for SA accumulation [52] and SA causes the up-regulation of EDS1 and PAD4 expression [113]. However, the SA role in plant productivity is not clear, since exogenous treatment with a low concentrations of SA increases the growth of soybean $[114]$, wheat $[115,116]$ and maize [117], while exogenous SA treatment with a higher SA concentration can inversely influence plant growth [118]. The impact of SA levels on plant growth and biomass production is presented in Table 1.

Table 1. Effect of mutation, gene silencing or bacterial genes expression in plant on SA level and plant phenotype.

\begin{tabular}{|c|c|c|c|c|}
\hline Organism & $\begin{array}{l}\text { Mutation, Transgene or } \\
\text { Gene Silencing }\end{array}$ & Effect on SA Level & Growth Phenotype & Reference \\
\hline Arabidopsis thaliana & Bacterial NahG expression & $\begin{array}{l}\text { Lower level of SA } \\
\text { in transgenic plants }\end{array}$ & $\begin{array}{l}\text { Higher biomass, } \\
\text { higher seed yield }\end{array}$ & [106] \\
\hline Arabidopsis thaliana & Mutation in ICS1 & $\begin{array}{l}\text { Lower level of SA } \\
\text { in the mutant }\end{array}$ & $\begin{array}{l}\text { Higher biomass, } \\
\text { higher seed yield }\end{array}$ & [106] \\
\hline Arabidopsis thaliana & Mutation in $C P R 1$ & $\begin{array}{l}\text { A significantly } \\
\text { higher level of SA } \\
\text { in the mutant }\end{array}$ & Dwarf phenotype & [119] \\
\hline Arabidopsis thaliana & Mutation in LSD1 & $\begin{array}{l}\text { A significantly } \\
\text { higher level of SA } \\
\text { in the mutant }\end{array}$ & Lower seed yield & [35] \\
\hline Arabidopsis thaliana & Mutation in $M P K 4$ & $\begin{array}{l}\text { A significantly } \\
\text { higher level of SA } \\
\text { in the mutant }\end{array}$ & Dwarf phenotype & [120] \\
\hline $\begin{array}{c}\text { Populus tremula } x \\
\text { tremuloides }\end{array}$ & Lower expression of $P A D 4$ & $\begin{array}{l}\text { Lower level of SA } \\
\text { in transgenic lines }\end{array}$ & $\begin{array}{l}\text { Higher stem diameter, } \\
\text { higher \% of dry weight }\end{array}$ & {$[48,121]$} \\
\hline $\begin{array}{l}\text { Populus tremula } x \\
\text { tremuloides }\end{array}$ & Lower expression of EDS1 & $\begin{array}{l}\text { Lower level of SA } \\
\text { in transgenic lines }\end{array}$ & $\begin{array}{c}\text { Higher } \mathrm{CO}_{2} \\
\text { assimilation, changed } \\
\text { plant morphology }\end{array}$ & [38] \\
\hline $\begin{array}{l}\text { Populus tremula } x \\
\text { tremuloides }\end{array}$ & Lower expression of $M P K 4$ & $\begin{array}{l}\text { Two times higher } \\
\text { level of SA in } \\
\text { transgenic lines }\end{array}$ & $\begin{array}{l}\text { Lower perimeter of } \\
\text { main stem }\end{array}$ & [107] \\
\hline
\end{tabular}


It has been shown that the ROS levels in plant tissues are highly interconnected with ET [82,104], and cooperate in the regulation of plant productivity [122]. ET as a gaseous hormone can freely enter plant cells [123]. It regulates many aspects of plant physiological processes, such as ripening, abscission, vegetative development, senescence and response to stress [123-125]. In both shoots and roots, ET causes the inhibition of cell expansion, affecting plant growth [126,127] and biomass production [128]. EDS1 and PAD4 operate upstream of ET and ROS production during light stress responses, and together with LSD1 regulate the signaling of PCD, light acclimation and defense responses through redox changes of the PQ pool [47]. Mutant analysis confirms that LSD1 suppresses EDS1- and PAD4-dependent ROS and ET signaling, and that EIN2, the ET signal transduction protein, acts downstream of EDS1 and PAD4 [47]. Propagation of PCD in the $l s d 1$ mutant is also dependent upon EIN2, since the ein2/lsd1 double mutant has significantly reduced runaway cell death, compared with $l s d 1$ under stress conditions [47].

Further evidence points to an important role for photosynthesis, chloroplasts and the redox status of the PQ pool in regulating LSD1-, EDS1- and PAD4-modulated stress responses [51]. Plants evolved unique mechanisms that depend upon excess excitation energy and redox (including ROS) signaling, originating at the chloroplast. Such response systems are likely to be crucial for plant growth, biomass production and their development in the natural environment. Naturally occurring changes in light intensity, temperature and humidity make plant growth dependent on successful acclimation to fluctuating conditions. Taking into consideration the research described above, the LSD1/EDS1/PAD4 hub may be a key regulator of plant acclimation and defense responses, as well as potentially, plant growth and development.

\section{LSD1, EDS1, and PAD4 are Involved in Biomass Production, Seed Yield Regulation, and Water Use Efficiency in Arabidopsis thaliana}

Acclimation and defense responses are regulated by redox sensing and modifications in the proximity of photosystem II and non-photochemical quenching (NPQ), the redox status of glutathione and plastoquinone pools, photoelectrophysiological signaling, ROS metabolism, hormonal circuits and cellular light stress memory [52,79,98,129-132]. Disturbances or changes in these processes may significantly affect the balance between plant cell death and cell division processes, and thus acclimation responses, biomass production and growth, these being processes that are under the control of LSD1, EDS1 and PAD4 [48,50,51].

From the moment of its discovery, the $l s d 1$ mutant was described as a dwarf [36], due to $l s d 1$ rosette size, that in non-permissive conditions is significantly smaller compared to wild-type plants. Moreover, dry biomass of $l s d 1$ was significantly lower than wild type [48]. Interestingly, no significant differences were found between the biomass of $l s d 1$ mutants and wild-type plants under field conditions [45].

Under non-permissive conditions (long photoperiod, UV-C episode) the $l s d 1$ mutant produced less biomass than wild-type, eds1, or pad4 mutants [33,45,87]. Mutations in AtEDS1 and AtPAD4 result in a reversal of the $l s d 1$ phenotype, since double $e d s 1 / l s d 1$ and pad $4 / l s d 1$ mutants do not differ from the wild type in terms of biomass production [45].

The LSD1/EDS1/PAD4 hub is not only involved in vegetative growth regulation, but also in the regulation of inflorescence development and seed production. Under laboratory conditions, reduced inflorescence growth and lower seed yield were found in $l s d 1$, but not in double $e d s 1 / l s d 1$ and $l s d 1 /$ pad4 mutants $[35,45]$. Surprisingly, this phenomenon was not observed under field conditions, in which the inflorescence and seed yield were similar between wild type, $l s d 1$, eds 1, pad4, eds $1 / l s d 1$ and pad1/lsd1 mutants [35,45]. It was proposed that under natural conditions, the LSD1 suppressive role of cell death and its role in growth regulation are dependent upon other, yet unknown regulators. The fact that $l s d 1$ mutants differ from the wild type in terms of biomass, inflorescence development and seed yield in the laboratory, but not in the field [35,45], indicates that LSD1, EDS1 and PAD4 conditionally regulate the signaling pathways engaged in plant development. 
The amount of biomass produced by plants is determined, among others, by the availability of water [133]. Although the role of LSD1, EDS1 and PAD4 in the regulation of water use efficiency (WUE) is not clear, it was found that the $l s d 1$ mutant produces significantly less dry mass per $1 \mathrm{~mL}$ of water utilized, in comparison to the wild type under field conditions, whereas double mutants eds $1 / l s d 1$ and $p a d 4 / l s d 1$ exhibit similar WUE values to the wild type. Under laboratory conditions, no differences were found between $l s d 1$ and the wild type [35]. On the other hand, water loss, corresponding to transpiration, was reduced in both laboratory- and field-grown $l s d 1$ mutants, compared to wild type [48]. Lower water requirements dependent upon LSD1 could be only partly explained by lower stomata density, because a noticeable decrease in stomata number seems to have an effect only on $l s d 1$ plants grown under stable laboratory conditions, but not under multivariable field conditions [48]. Therefore, other mechanisms should be considered in explaining this LSD1-dependent control of water loss (stomatal regulation), and its utilization. SA, ET and $\mathrm{H}_{2} \mathrm{O}_{2}$, which are important during photosynthesis and the control of stomatal conductance [134-137], can be potential candidates. Indeed, mathematical models confirm that LSD1, EDS1 and PAD4, together with SA and $\mathrm{H}_{2} \mathrm{O}_{2}$, are involved in the regulation of water use efficiency (WUE) and vegetative and generative development [45]. Additionally, a strong correlation between SA and $\mathrm{H}_{2} \mathrm{O}_{2}$ content in 4-week-old plants and seed yield, determined for 9-week-old plants, may indicate that mechanisms dependent upon LSD1, EDS1 and PAD4 are involved in the algorithmic computation performed by plants, in order to optimize ROS and hormone content at early stages of plant development, in order to ensure maximal seed yield.

In summary, LSD1, EDS1 and PAD4 constitute a signaling hub, which integrates plant responses to water stress, vegetative biomass production and generative development. This hub plays a significant role in at least in two different species, Arabidopsis thaliana and Populus tremula $\times$ P. tremuloides.

\section{LSD1, EDS1, and PAD4 Regulate Morphology, Photosynthetic Efficiency, and Wood Properties in Populus tremula L. $\times$ P. tremuloides}

Poplar, referred to as the "Arabidopsis of forestry" [138], is widely used for the study of molecular mechanisms, as well as for industrial applications, mainly paper and bioethanol production $[139,140]$. Thanks to the availability of genetic engineering methods, new poplar genotypes with improved growth and biomass accumulation were created $[38,107,121,141,142]$. Biomass accumulation in woody plants is strictly related to cell division at the primary and secondary meristems [143]. Therefore, plant growth and biomass production can be improved by an overall increase in cell number [144-146], which is under the control of genes involved in cell cycle regulation $[147,148]$ or hormone biosynthesis $[149,150]$.

Down-regulation of $L S D 1, E D S 1$, and PAD4 affects poplar growth and biomass accumulation [48]. In transgenic poplar lines LSD1-RNAi, EDS1-RNAi and PAD4-RNAi were found a higher number of cells, but only in PAD4-RNAi and LSD1-RNAi lines did it result in larger stem diameter and stem length [48]. Nevertheless, a greater number of lateral shoots was observed in EDS1-RNAi lines, and this may also result in improved total biomass production [38]. Furthermore, LSD1, EDS1 and PAD4 influence wood structure. The cell wall was thicker in all LSD1-, EDS1- and PAD4-silenced lines, among others as a result of changes in the cell wall composition. The increase in hemicelluloses, decline in cellulose, and reduced lignin quantity and stability in the LSD1-RNA $i$ wood, resulted in easy wood degradation, which may be important for its improved industrial application. In contrast, the cell wall of PAD4-RNAi trees had more cellulose and lignin, and less hemicelluloses, and was more resistant to degradation (Figure 2). 


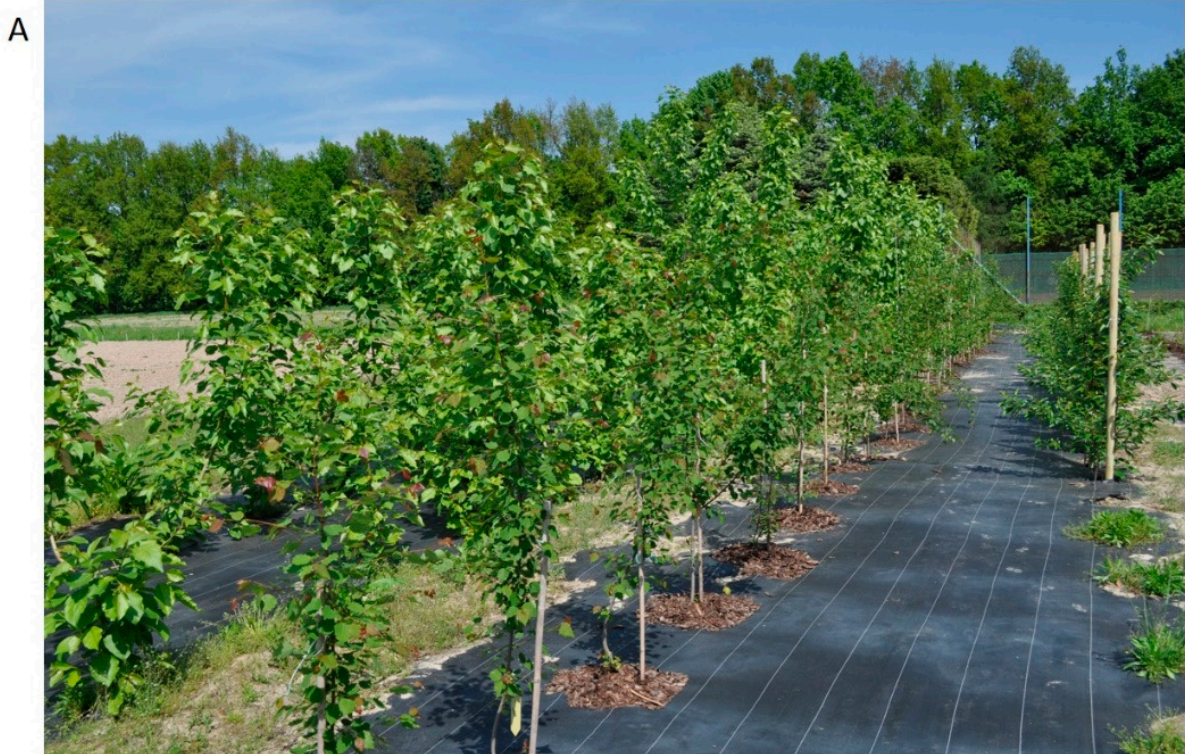

B

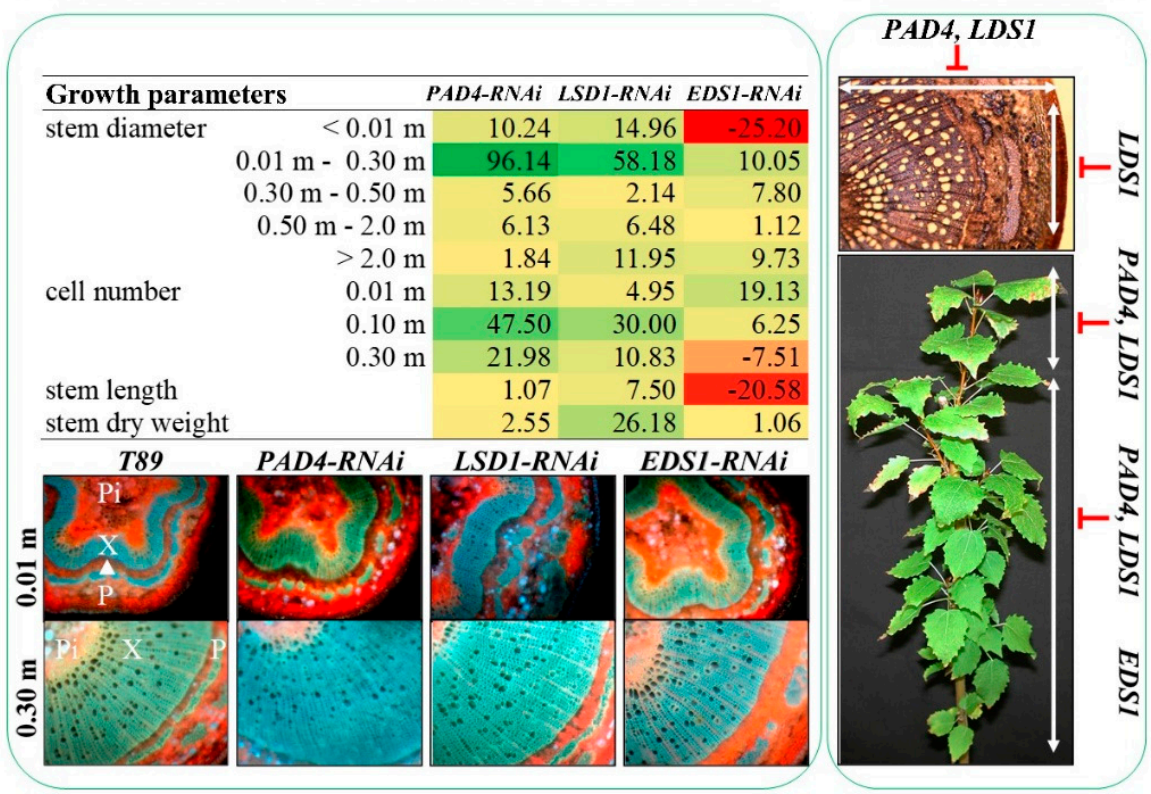

Figure 2. Photograph of transgenic poplar plantation (A), and the regulation of tree growth by LSD1, EDS1 and PAD4 (B). Percentage changes in growth parameters are presented in relation to wild-type trees (T89). Lower expression of LSD1 and PAD4, but not EDS1, increased biomass accumulation, measured as stem length and diameter, stem dry weight and xylem accumulation. Higher cell numbers and improved diameters were observed in young parts of the stems of PAD4-RNAi trees, while LSD1-RNA $i$ trees also displayed a higher diameter of the older part of the stem, accompanied by higher stem length. Fluorescent microscopy of stem cross-sections demonstrate: $P i=$ pith, $X=$ xylem; $\Delta=$ cambium,$P=$ phloem. Based on these results the following model was suggested: PAD4 deregulates (inhibits) periclinal cell division. LSD1 has a significant effect upon both periclinal and anticlinal divisions, on cell elongation and differentiation, while EDS1 is a positive regulator of cell division and differentiation in poplars $[38,48]$.

These changes may be linked to higher $\mathrm{H}_{2} \mathrm{O}_{2}$ content in poplar transgenic lines [38,121], since ROS are important in the development of the cell wall [86,151-154]. $\mathrm{H}_{2} \mathrm{O}_{2}$ is involved in the differentiation of secondary cell walls and in the polymerization of cinnamyl alcohols in lignifying xylem vessels $[155,156]$. Moreover, SA is an important component of signaling pathways engaged in plant cell growth [157]. Lower levels of SA were found in poplar lines with silenced EDS1 [38]. These results suggest that it is 
possible to engineer the plant cell-walls without negative impact on their growth and development. From the wood industry point of view, i.e., the production of paper and bioethanol, material obtained from such wood is cheaper, and its production is less harmful for the environment [158].

Since biomass production is tightly dependent upon photosynthesis [159], it is not surprising that producing more abundant lateral shoots in the EDS1-RNAi lines correlates with improved photosynthetic parameters (quantum yield of photosystem II, photochemical and non-photochemical quenching), chlorophyll content, and thus photosynthetic efficiency. Moreover, EDS1-silenced trees have a higher $\mathrm{CO}_{2}$ assimilation and photosynthetic capacity and maintain their leaves longer, since processes involved in senescence are delayed [38].

\section{Orthologs of LSD1, EDS1, and PAD4 in Crops}

Orthologs of LSD1, EDS1 and PAD4 were found in many plant species, including crops and industrial plants (Table 2). While most model plants are dicotyledonous, many crop plants are monocotyledonous. However, it was postulated that despite some clade/species-specific changes, an evolutionarily-conserved regulon containing core components of plant innate immunity is present [160]. LSD1, EDS1 and PAD4 originated prior to the differentiation of monocots and dicots [24]. Despite some structural differences, LSD1, EDS1 and PAD4 seem to have a similar function in all plant species where they are identified. The different crops described below are of great importance in agriculture, and thus genes involved in their resistance, biomass production, productivity and development are important from the agricultural point of view.

Rice (Oryza sativa) is one of the most important crops, and is a crucial dietary component for over 3.5 billion people [161]. Approximately 480 million metric tons of rice is produced annually [162]. Rice was the first fully-sequenced crop [163], which makes genetic studies of rice relatively easy. Orthologs of AtLSD1, AtEDS1 and AtPAD4 were found in rice [22,23] (Table 2). Similarly to Arabidopsis, LSD1 in rice is light-induced and dark-suppressed [23,41,47]. In LSD1 antisense transgenic rice, a higher expression of PR1 and a lesion phenotype was observed, which indicates that LSD1 is a negative regulator of cell death in rice [23]. Expression of OsLSD1 in Nicotiana tabacum was shown to enhance resistance to mycotoxins [23]. Furthermore, the regulation of PCD by OsLSD1 occurs through direct interactions of LSD1 with rice metacaspase (OsMC) [164], similar to Arabidopsis, where AtLSD1-dependent cell death is associated with metacaspase activity [60]. To date, no studies were performed on mutants or transgenic crop plants with deregulated expression of the OsEDS1. However, the expression of OsEDS1 was shown to be upregulated in response to biotic stress and SA treatment $[165,166]$. Interestingly, the function of OsPAD4 is different from AtPAD4 [22]. While AtPAD4 is localized in the cytoplasm and nucleus [50,167], OsPAD4 encodes a plasma membrane protein [22]. Furthermore, the AtPAD4-induced pathway against biotrophic pathogens is SA-dependent, while OsPAD4 is involved in JA-dependent defense responses [22]. OsPAD4-silenced plants exhibit enhanced susceptibility to biotrophic pathogens associated with impaired accumulation of jasmonic acid (JA) and phytoalexinmomilactone A (MOA) [22]. Moreover, exogenous JA application complemented the susceptibility phenotype of OsPAD4-silenced rice [22].

Grape (Vitis vinifera) is an important fruit plant with world production of about 27 million tons [168]. This plant is susceptible to infection, especially by fungi [28,169-173]. However, there is currently no information about LSD1 orthologs in Vitis vinifera, or also studies were not carried out on grapes with deregulated $V v L S D 1$ expression, or even the VvLSD1 expression profile was not investigated. In contrast, Vitis vinifera orthologs of AtEDS1 and AtPAD4 have been studied in grape [28,29,174,175], and EDS1-LIKE (EDL) genes were found in the grape genome [29]. There is a molecular evidence that EDS1 and PAD4 form a stable complex in grape, which supports the SA defense pathway in response to biotic stress $[29,175]$. However, it was postulated that the EDS1/PAD4 hub in grape is more complicated, compared to Arabidopsis [29]. The expression of VvEDS1 and $V v E D L$ was up-regulated by pathogens $[28,174]$ and that of $V v E D S 1$ additionally by SA [29]. VvEDS1 expression complemented the Arabidopsis eds1 phenotype, whereas the expression of VvPAD4 did not 
complement the pad4 mutant phenotype. Interestingly, VvEDS1 and VvEDL proteins can interact not only with VvPAD4, but also with AtPAD4, while VvPAD4 cannot interact with AtEDS1 [29]. These results support a similar role for EDS1 in grape and Arabidopsis, but also show some differences between AtPAD4 and VvPAD4.

Cotton (Gossypium barbadense) is widely used in textile, feed, food, biooil and biofuel production [176]. Cotton crops are susceptible to pathogens such as Verticillium dahlia, which significantly reduces yield $[177,178]$. An ortholog of AtEDS1 was found in cotton with an amino acid sequence similarity of $46 \%, 53 \%$, and $54 \%$ with Arabidopsis thaliana, Solanum lycopersicum and Nicotiana benthamiana, respectively. Similarly to EDS1 orthologs from other species, GbEDS1 contains a conserved N-terminal lipase domain and an EDS1-specific KNEDT motif, and is localized to both the cytoplasm and nucleus [26]. GbEDS1 expression is drastically increased in response to pathogens [26,27]. Moreover, overexpression of GbEDS1 triggers higher $\mathrm{SA}$ and $\mathrm{H}_{2} \mathrm{O}_{2}$ production, while its silencing results in significantly-decreased $\mathrm{SA}$ and $\mathrm{H}_{2} \mathrm{O}_{2}$ accumulation [27]. It was found that orthologs of AtPAD4 were up-regulated in cotton during pathogen infection [178]. So far, no data describing the role of LSD1 in cotton was shown.

A functional homolog to AtLSD1 and orthologs of AtEDS1 were found in Triticum aestivum. [24,25]. TaLSD1 encodes 146 amino acid long protein, which contains three zinc-finger domains, similarly to AtLSD1 [61]. Generally, TaLSD1 is a regulator of cell death and is involved in disease resistance of wheat against pathogens [25]. This suggests that the role of $A t \mathrm{LSD} 1$ and TaLSD1 is similar [43,61]. The expression of TaLSD1 is up-regulated during interaction with the fungal pathogen, Puccinia striiformis, and in response to oxidative stress-generating compound methyl viologen [25]. Using an onion epidermal system, TaLSD1 was found in the nucleus [25]. Interestingly, TaLSD1 overexpression in Nicotiana benthamiana inhibits cell death induced by the expression of the mammalian BAX gene, which encodes a regulator of apoptosis [179-181]. Moreover, silencing of TaLSD1 in wheat resulted in higher TaPR1 expression and enhanced hypersensitive response [25]. TaEDS1 was also described recently in wheat [24]. Three orthologs of AtEDS1 were found in the Triticum aestivum genome (TaEDS1-5A, $5 B$ and $5 D$ ). The similarity between these TaEDS1 cDNA sequences was greater than $96 \%$. Moreover, TaEDS1-5A, 5B and 5D genes share sequence similarity of about $99 \%$ with the respective diploid ancestor orthologs. TaEDS1 is strongly up-regulated in response to pathogen and SA treatment [24]. Most importantly, the expression of TaEDS1 in the eds1 mutant complemented its susceptible phenotype to powdery mildew [24].

Orthologs of AtLSD1 or AtEDS1 have been also found in crops such as Solanum melongena, Lycopersicon esculentum, Pisum sativum, Glycine max and Solanum tuberosum [30,32,182-184]. LeEDS1 is involved in SA accumulation since tomato $e d s 1$ mutants have significantly reduced SA level and impaired R gene-mediated resistance to viral, bacterial, and fungal pathogens [30]. It was also reported that tomato EDS1 is involved in both basal and $R$ gene-mediated resistance [30,31], and its expression is up-regulated in response to pathogen infection $[185,186]$. Moreover, it was found that LePAD4 expression is up-regulated in response to green peach aphid [187]. A single copy of SmEDS1 was mined from the Solanum melongena genome draft. Using bioinformatic methods, it was determined that the full-length $S m E D S 1$ gene is $4.5 \mathrm{~kb}$ long and contains three exons coding for $1.8 \mathrm{~kb}$ mRNA. The described gene encodes a protein consisting of 602 amino acids [184]. 
Table 2. Characterized orthologs of LSD1, EDS1 and PAD4 in crops.

\begin{tabular}{ccc}
\hline Ortholog of: & Species & Reference \\
\hline \multirow{2}{*}{ AtLSD1 } & Oryza sativa & {$[23]$} \\
& Triticum aestivum & {$[25]$} \\
& Pisum sativum & {$[32]$} \\
\hline \multirow{2}{*}{ AtEDS1 } & Oryza sativa, & {$[166]$} \\
& Gossypium barbadense & {$[26,27]$} \\
& Vitis vinifera & {$[28,176]$} \\
& Lycopersicon esculentum & {$[30,186,188]$} \\
AtPAD4 & Triticum aestivum & {$[24]$} \\
& Oryza sativa & {$[22]$} \\
& Vitis vinifera, & {$[176]$} \\
& Gossypium barbadense & {$[179]$} \\
\hline
\end{tabular}

The LSD1 protein has been well characterized in Pisum sativum [32]. It was found that PsLSD1 is involved in PCD regulation and the overexpression of PsLSD1 in the Arabidopsis lsd1 mutant reverts the RCD phenotype in response to SA treatment [32]. It was shown that PsLSD1 is a nuclear-localized protein containing zinc finger motifs, and can act as a transcription regulator [32], similar to AtLSD1 [50]. The Glycine max genome encodes two EDS1 isoforms and one PAD4 ortholog. GmEDS1 and GmPAD4 are necessary for defense signaling in Glycine max, and their structure is similar to AtEDS1 and AtPAD4, respectively. Moreover, the expression of GmEDS1 and GmPAD4 in eds1 and pad4 mutants complemented their pathogen-resistant phenotypes [188], while the expression of GmEDS1 and GmPAD4 in eds1/pad4 double mutant did not complement pathogen-induced SA accumulation [188]. Importantly, transgenic soybean lines with silenced GmEDS1 or GmPAD4 demonstrated reduced basal and pathogen-induced SA accumulation and increased susceptibility to virulent pathogens [188]. GmLSD1 is involved in response to biotic stress, and GmLSD1 is a negative regulator of cell death [183]. In addition, genomic sequences of StEDS1 and StPAD4 were obtained from the potato genome [182]. All those studies seem to be a great starting point for future research, cloning and expression analysis of LSD1, EDS1 and PAD4 genes.

\section{Future Perspectives}

The role of LSD1, EDS1 and PAD4 is well known in model plants, such as Arabidopsis thaliana, Nicotiana benthamiana and Populus tremula $\times$ P. tremuloides, but some mechanism and dependencies are still unknown. The function of LSD1, EDS1 and PAD4 appears to be highly conserved, and is similar in many plant species, both monocots and dicots. Because of their high importance, the function of these proteins should be studied further in model plants, and new knowledge should be transferred to crops and industrial plants.

In this article, we described different examples suggesting that manipulating LSD1, EDS1 and $P A D 4$ could be beneficial and useful for enhanced agriculture production. To date, no studies have been performed on crops with modified expressions of LSD1, EDS1 and PAD4 orthologs in the context of yield and biomass production. Interestingly, the role of AtPAD4 orthologs in crops seems to be different from its role in model plants [22]. Precise determination of the role of LSD1, EDS1 and PAD4 in the regulation of plant productivity and their role in regulating SA/ROS homeostasis may allow faster crop selection in the future. Climate change impacts also involve a reduction in the availability of water resources. Therefore, the role of proteins, that can participate in the regulation of the WUE, such as LSD1, EDS1 and PAD4, should be studied.

Climate change causes not only stronger and more frequent abiotic stress, such as heat, high light or drought, but also more intense biotic stresses. It is estimated that in the near future, losses to agricultural production associated with excessive stress may increase by $10-25 \%$. LSD1, EDS1 and PAD4 have been described as universal regulators of responses to both biotic and abiotic stresses in 
Arabidopsis thaliana, but also potentially in crops. Therefore, manipulating their expression could be an interesting alternative for adapting different crop varieties to climate change. The different LSD1, EDS1 and PAD4 mutants have also been used as an example in the development of algorithms to determine future yield at early stages of cultivation, based upon some physiological traits. Implementing such algorithms could significantly accelerate the breeding process and reduce the cost of agricultural production. Manipulating genes involved in responses to biotic stress in order to improve plant yield or biomass production may carry the risk of greater susceptibility to pathogens. However, our 10 year-long field experiment with poplar and Arabidopsis thaliana did not show increased susceptibility to pathogens in any of the mutants or silenced lines tested.

Author Contributions: M.J.B., W.C. and M.S.-H. wrote the manuscript with the help of R.M. and S.K. We thank Damian Witon for providing the picture of poplar trees grown in the field.

Funding: This work was supported by the 'Maestro 6' project (2014/14/A/NZ1/00218) granted to S.K. by the National Science Centre. M.J.B. is financially supported by The financial Supports for Young Scientists (WULS-SGGW International Research Scholarship Fund No. BWM 315-2018).

Conflicts of Interest: The authors declare no conflict of interest.

\section{References}

1. Atafar, Z.; Mesdaghinia, A.; Nouri, J.; Homaee, M.; Yunesian, M.; Ahmadimoghaddam, M.; Mahvi, A.H. Effect of fertilizer application on soil heavy metal concentration. Environ. Monit. Assess. 2010, 160, 83-89. [CrossRef] [PubMed]

2. Cohen, M. Environmental toxins and health: The health impact of pesticides. Aust. Fam. Phys. Melb. 2007, 36, 1002-1004.

3. Geiger, F.; Bengtsson, J.; Berendse, F.; Weisser, W.W.; Emmerson, M.; Morales, M.B.; Ceryngier, P.; Liira, J.; Tscharntke, T.; Winqvist, C.; et al. Persistent negative effects of pesticides on biodiversity and biological control potential on European farmland. Basic Appl. Ecol. 2010, 11, 97-105. [CrossRef]

4. Van der Werf, H.M.G. Assessing the impact of pesticides on the environment. Agric. Ecosyst. Environ. 1996, 60, 81-96. [CrossRef]

5. Wilson, C.; Tisdell, C. Why farmers continue to use pesticides despite environmental, health and sustainability costs. Ecol. Econ. 2001, 39, 449-462. [CrossRef]

6. Bernacki, Z. Biomass production of maize (Zea mays L.) cropping in exceptionally advantageous conditions in central Wielkopolska (Poland). Biomass Bioenergy 2018, 110, 25-32. [CrossRef]

7. Kundzewicz, Z.W.; Krysanova, V.; Benestad, R.E.; Hov, Ø.; Piniewski, M.; Otto, I.M. Uncertainty in climate change impacts on water resources. Environ. Sci. Policy 2018, 79, 1-8. [CrossRef]

8. Polley, H.W. Implications of atmospheric and climatic change for crop yield and water use efficiency. Crop Sci. 2002, 42, 131-140. [CrossRef]

9. Tambussi, E.A.; Bort, J.; Araus, J. Water use efficiency in C3 cereals under Mediterranean conditions: A review of physiological aspects. Ann. Appl. Biol. 2007, 150, 307-321. [CrossRef]

10. Kausch, A.; Rhodes, R. Research and Technology Development for Genetic Improvement of Switchgrass; Univ. of Rhode Island: Kingston, RI, USA, 2014. Available online: https://www.osti.gov/servlets/purl/1357908 (accessed on 27 May 2019).

11. Padgette, S.R.; Kolacz, K.H.; Delannay, X.; Re, D.B.; LaVallee, B.J.; Tinius, C.N.; Rhodes, W.K.; Otero, Y.I.; Barry, G.F.; Eichholtz, D.A.; et al. Development, identification, and characterization of a glyphosate-tolerant soybean line. Crop Sci. 1995, 35, 1451-1461. [CrossRef]

12. Huang, J.; Rozelle, S.; Pray, C.; Wang, Q. Plant biotechnology in China. Science 2002, 295, 674-676. [CrossRef] [PubMed]

13. Sasson, A.; Malpica, C. Bioeconomy in Latin America. New Biotechnol. 2018, 40, 40-45. [CrossRef] [PubMed]

14. Yan, L.; Kerr, P.S. Genetically-engineered crops: Their potential use for improvement of human nutrition. Nutr. Rev. 2002, 60, 135-141. [CrossRef] [PubMed]

15. Brookes, G.; Barfoot, P. The global income and production effects of genetically-modified (GM) crops 1996-2011. GM Crops Food 2013, 4, 74-83. [CrossRef] [PubMed] 
16. Benbrook, C.M. Trends in glyphosate herbicide use in the United States and globally. Environ. Sci. Eur. 2016, 28, 3. [CrossRef] [PubMed]

17. Shewry, P.R.; Jones, H.D.; Halford, N.G. Plant Biotechnology: Transgenic Crops. In Food Biotechnology; Advances in Biochemical Engineering/Biotechnology; Springer: Berlin/Heidelberg, Germany, 2008; pp. 149-186. ISBN 978-3-540-70535-2.

18. Szechyńska-Hebda, M.; Wędzony, M.; Tyrka, M.; Gołębiowska, G.; Chrupek, M.; Czyczyło-Mysza, I.; Dubas, E.; Żur, I.; Golemiec, E. Identifying QTLs for cold-induced resistance to Microdochium nivale in winter triticale. Plant Genet. Resour. 2011, 9, 296-299. [CrossRef]

19. Szechyńska-Hebda, M.; Wąsek, I.; Gołębiowska-Pikania, G.; Dubas, E.; Żur, I.; Wędzony, M. Photosynthesis-dependent physiological and genetic crosstalk between cold acclimation and cold-induced resistance to fungal pathogens in triticale (Triticosecale Wittm.). J. Plant Physiol. 2015, 177, 30-43. [CrossRef] [PubMed]

20. Voytas, D.F.; Gao, C. Precision genome engineering and agriculture: Opportunities and regulatory challenges. PLoS Biol. 2014, 12, e1001877. [CrossRef]

21. Somerville, C.; Youngs, H.; Taylor, C.; Davis, S.C.; Long, S.P. Feedstocks for lignocellulosic biofuels. Science 2010, 329, 790-792. [CrossRef]

22. Ke, Y.; Liu, H.; Li, X.; Xiao, J.; Wang, S. Rice OsPAD4 functions differently from Arabidopsis AtPAD4 in host-pathogen interactions. Plant J. 2014, 78, 619-631. [CrossRef]

23. Wang, L.; Pei, Z.; Tian, Y.; He, C. OsLSD1, a rice zinc finger protein, regulates programmed cell death and callus differentiation. Mol. Plant. Microbe Interact. 2005, 18, 375-384. [CrossRef] [PubMed]

24. Chen, G.; Wei, B.; Li, G.; Gong, C.; Fan, R.; Zhang, X. TaEDS1 genes positively regulate resistance to powdery mildew in wheat. Plant Mol. Biol. 2018, 96, 607-625. [CrossRef] [PubMed]

25. Guo, J.; Bai, P.; Yang, Q.; Liu, F.; Wang, X.; Huang, L.; Kang, Z. Wheat zinc finger protein TaLSD1, a negative regulator of programmed cell death, is involved in wheat resistance against stripe rust fungus. Plant Physiol. Biochem. 2013, 71, 164-172. [CrossRef] [PubMed]

26. Su, X.; Qi, X.; Cheng, H. Molecular cloning and characterization of enhanced disease susceptibility 1 (EDS1) from Gossypium barbadense. Mol. Biol. Rep. 2014, 41, 3821-3828. [CrossRef] [PubMed]

27. Yan, Z.; Xingfen, W.; Wei, R.; Jun, Y.; Zhiying, M. Island cotton enhanced disease susceptibility 1 gene encoding a lipase-like protein plays a crucial role in response to Verticillium dahliae by regulating the SA level and $\mathrm{H}_{2} \mathrm{O}_{2}$ accumulation. Front. Plant Sci. 2016, 7, 1830. [CrossRef] [PubMed]

28. Gao, F.; Shu, X.; Ali, M.B.; Howard, S.; Li, N.; Winterhagen, P.; Qiu, W.; Gassmann, W. A functional EDS1 ortholog is differentially regulated in powdery mildew resistant and susceptible grapevines and complements an Arabidopsis eds1 mutant. Planta 2010, 231, 1037-1047. [CrossRef] [PubMed]

29. Gao, F.; Dai, R.; Pike, S.M.; Qiu, W.; Gassmann, W. Functions of EDS1-like and PAD4 genes in grapevine defenses against powdery mildew. Plant Mol. Biol. 2014, 86, 381-393. [CrossRef]

30. Hu, G.; deHart, A.K.A.; Li, Y.; Ustach, C.; Handley, V.; Navarre, R.; Hwang, C.-F.; Aegerter, B.J.; Williamson, V.M.; Baker, B. EDS1 in tomato is required for resistance mediated by TIR-class R genes and the receptor-like R gene Ve. Plant J. Cell Mol. Biol. 2005, 42, 376-391. [CrossRef]

31. Schornack, S.; Ballvora, A.; Gürlebeck, D.; Peart, J.; Baulcombe, D.; Ganal, M.; Baker, B.; Bonas, U.; Lahaye, T. The tomato resistance protein Bs4 is a predicted non-nuclear TIR-NB-LRR protein that mediates defense responses to severely truncated derivatives of AvrBs4 and overexpressed AvrBs3. Plant J. Cell Mol. Biol. 2004, 37, 46-60. [CrossRef]

32. He, S.; Huang, K.; Zhang, X.; Yu, X.; Huang, P.; An, C. The LSD1-type zinc finger motifs of Pisum sativa LSD1 are a novel nuclear localization signal and interact with importin alpha. PLoS ONE 2011, 6, e22131. [CrossRef]

33. Lorrain, S.; Vailleau, F.; Balagué, C.; Roby, D. Lesion mimic mutants: keys for deciphering cell death and defense pathways in plants? Trends Plant Sci. 2003, 8, 263-271. [CrossRef]

34. Salmeron, J.M.; Vernooij, B. Transgenic approaches to microbial disease resistance in crop plants. Curr. Opin. Plant Biol. 1998, 1, 347-352. [CrossRef] 
35. Wituszyńska, W.; Ślesak, I.; Vanderauwera, S.; Szechyńska-Hebda, M.; Kornaś, A.; Kelen, K.V.D.; Mühlenbock, P.; Karpińska, B.; Maćkowski, S.; Breusegem, F.V.; et al. LESION SIMULATING DISEASE 1, ENHANCED DISEASE SUSCEPTIBILITY 1, and PHYTOALEXIN DEFICIENT 4 conditionally regulate cellular signaling homeostasis, photosynthesis, water use efficiency, and seed yield in Arabidopsis. Plant Physiol. 2013, 161, 1795-1805. [CrossRef] [PubMed]

36. Dietrich, R.A.; Delaney, T.P.; Uknes, S.J.; Ward, E.R.; Ryals, J.A.; Dangl, J.L. Arabidopsis mutants simulating disease resistance response. Cell 1994, 77, 565-577. [CrossRef]

37. Jabs, T.; Dietrich, R.A.; Dangl, J.L. Initiation of runaway cell death in an Arabidopsis mutant by extracellular superoxide. Science 1996, 273, 1853-1856. [CrossRef]

38. Bernacki, M.J.; Czarnocka, W.; Witoń, D.; Rusaczonek, A.; Szechyńska-Hebda, M.; Ślesak, I.; Dąbrowska-Bronk, J.; Karpiński, S. ENHANCED DISEASE SUSCEPTIBILITY 1 (EDS1) affects development, photosynthesis, and hormonal homeostasis in hybrid aspen (Populus tremula L. $\times$ P. tremuloides). J. Plant Physiol. 2018, 226, 91-102. [CrossRef] [PubMed]

39. Huang, C.H.; Kuo, W.Y.; Weiss, C.; Jinn, T.L. Copper chaperone-dependent and -Independent activation of three copper-zinc superoxide dismutase homologs localized in different cellular compartments in Arabidopsis. Plant Physiol. 2012, 158, 737-746. [CrossRef]

40. Mateo, A.; Funck, D.; Mühlenbock, P.; Kular, B.; Mullineaux, P.M.; Karpinski, S. Controlled levels of salicylic acid are required for optimal photosynthesis and redox homeostasis. J. Exp. Bot. 2006, 57, 1795-1807. [CrossRef]

41. Mateo, A.; Mühlenbock, P.; Rustérucci, C.; Chang, C.C.C.; Miszalski, Z.; Karpinska, B.; Parker, J.E.; Mullineaux, P.M.; Karpinski, S. LESION SIMULATING DISEASE 1 is required for acclimation to conditions that promote excess excitation energy. Plant Physiol. 2004, 136, 2818-2830. [CrossRef]

42. Mühlenbock, P.; Plaszczyca, M.; Plaszczyca, M.; Mellerowicz, E.; Karpinski, S. Lysigenous aerenchyma formation in Arabidopsis is Controlled by LESION SIMULATING DISEASE1. Plant Cell 2007, 19, 3819-3830. [CrossRef]

43. Rustérucci, C.; Aviv, D.H.; Holt, B.F.; Dangl, J.L.; Parker, J.E. The disease resistance signaling components EDS1 and PAD4 are essential regulators of the cell death pathway controlled by LSD1 in Arabidopsis. Plant Cell 2001, 13, 2211-2224. [CrossRef] [PubMed]

44. Wituszyńska, W.; Szechyńska-Hebda, M.; Sobczak, M.; Rusaczonek, A.; Kozłowska-Makulska, A.; Witoń, D.; Karpiński, S. Lesion simulating disease 1 and enhanced disease susceptibility 1 differentially regulate UV-C-induced photooxidative stress signalling and programmed cell death in Arabidopsis thaliana. Plant Cell Environ. 2015, 38, 315-330. [CrossRef] [PubMed]

45. Bernacki, M.J.; Czarnocka, W.; Rusaczonek, A.; Witoń, D.; Kęska, S.; Czyż, J.; Szechyńska-Hebda, M.; Karpiński, S. LSD1, EDS1 and PAD4-dependent conditional correlation among salicylic acid, hydrogen peroxide, water use efficiency, and seed yield in Arabidopsis thaliana. Physiol. Plant. 2018, 165, 369-382. [CrossRef] [PubMed]

46. Aviv, D.H.; Rustérucci, C.; Iii, B.F.H.; Dietrich, R.A.; Parker, J.E.; Dangl, J.L. Runaway cell death, but not basal disease resistance, in lsd1 is SA- and NIM1/NPR1-dependent. Plant J. 2002, 29, 381-391. [CrossRef] [PubMed]

47. Mühlenbock, P.; Szechynska-Hebda, M.; Plaszczyca, M.; Baudo, M.; Mateo, A.; Mullineaux, P.M.; Parker, J.E.; Karpinska, B.; Karpinski, S. Chloroplast signaling and LESION SIMULATING DISEASE1 regulate crosstalk between light acclimation and immunity in Arabidopsis. Plant Cell 2008, 20, 2339-2356. [CrossRef] [PubMed]

48. Szechyńska-Hebda, M.; Czarnocka, W.; Hebda, M.; Karpiński, S. PAD4, LSD1 and EDS1 regulate drought tolerance, plant biomass production, and cell wall properties. Plant Cell Rep. 2016, 35, 527-539. [CrossRef]

49. Huang, X.; Li, Y.; Zhang, X.; Zuo, J.; Yang, S. The Arabidopsis LSD1 gene plays an important role in the regulation of low temperature-dependent cell death. New Phytol. 2010, 187, 301-312. [CrossRef]

50. Czarnocka, W.; Van Der Kelen, K.; Willems, P.; Szechyńska-Hebda, M.; Shahnejat-Bushehri, S.; Balazadeh, S.; Rusaczonek, A.; Mueller-Roeber, B.; Van Breusegem, F.; Karpiński, S. The dual role of LESION SIMULATING DISEASE 1 as a condition-dependent scaffold protein and transcription regulator: Insight into the LSD1 molecular function. Plant Cell Environ. 2017, 40, 2644-2662. [CrossRef]

51. Karpiński, S.; Szechyńska-Hebda, M.; Wituszyńska, W.; Burdiak, P. Light acclimation, retrograde signalling, cell death and immune defences in plants. Plant Cell Environ. 2013, 36, 736-744. [CrossRef] 
52. Rietz, S.; Stamm, A.; Malonek, S.; Wagner, S.; Becker, D.; Medina-Escobar, N.; Vlot, A.C.; Feys, B.J.; Niefind, K.; Parker, J.E. Different roles of enhanced disease susceptibility1 (EDS1) bound to and dissociated from Phytoalexin Deficient4 (PAD4) in Arabidopsis immunity. New Phytol. 2011, 191, 107-119. [CrossRef]

53. Feys, B.J.; Moisan, L.J.; Newman, M.A.; Parker, J.E. Direct interaction between the Arabidopsis disease resistance signaling proteins, EDS1 and PAD4. EMBO J. 2001, 20, 5400-5411. [CrossRef] [PubMed]

54. Falk, A.; Feys, B.J.; Frost, L.N.; Jones, J.D.G.; Daniels, M.J.; Parker, J.E. EDS1, an essential component of R gene-mediated disease resistance in Arabidopsis has homology to eukaryotic lipases. Proc. Natl. Acad. Sci. USA 1999, 96, 3292-3297. [CrossRef] [PubMed]

55. Jirage, D.; Tootle, T.L.; Reuber, T.L.; Frost, L.N.; Feys, B.J.; Parker, J.E.; Ausubel, F.M.; Glazebrook, J. Arabidopsis thaliana PAD4 encodes a lipase-like gene that is important for salicylic acid signaling. Proc. Natl. Acad. Sci. USA 1999, 96, 13583-13588. [CrossRef] [PubMed]

56. Aarts, N.; Metz, M.; Holub, E.; Staskawicz, B.J.; Daniels, M.J.; Parker, J.E. Different requirements for EDS1 and NDR1 by disease resistance genes define at least two R gene-mediated signaling pathways in Arabidopsis. Proc. Natl. Acad. Sci. USA 1998, 95, 10306-10311. [CrossRef] [PubMed]

57. Parker, J.E.; Holub, E.B.; Frost, L.N.; Falk, A.; Gunn, N.D.; Daniels, M.J. Characterization of eds1, a mutation in Arabidopsis suppressing resistance to Peronospora parasitica specified by several different RPP genes. Plant Cell 1996, 8, 2033-2046.

58. Wiermer, M.; Feys, B.J.; Parker, J.E. Plant immunity: the EDS1 regulatory node. Curr. Opin. Plant Biol. 2005, 8, 383-389. [CrossRef]

59. Drew, M.C.; He, C.J.; Morgan, P.W. Programmed cell death and aerenchyma formation in roots. Trends Plant Sci. 2000, 5, 123-127. [CrossRef]

60. Coll, N.S.; Vercammen, D.; Smidler, A.; Clover, C.; Van Breusegem, F.; Dangl, J.L.; Epple, P. Arabidopsis type I metacaspases control cell death. Science 2010, 330, 1393-1397. [CrossRef]

61. Dietrich, R.A.; Richberg, M.H.; Schmidt, R.; Dean, C.; Dangl, J.L. A novel zinc finger protein is encoded by the Arabidopsis LSD1 gene and functions as a negative regulator of plant cell death. Cell 1997, 88, 685-694. [CrossRef]

62. Takatsuji, H. Zinc-finger transcription factors in plants. Cell. Mol. Life Sci. CMLS 1998, 54, 582-596. [CrossRef]

63. Coll, N.S.; Epple, P.; Dangl, J.L. Programmed cell death in the plant immune system. Cell Death Differ. 2011, 18, 1247-1256. [CrossRef] [PubMed]

64. Chai, T.; Zhou, J.; Liu, J.; Xing, D. LSD1 and HY5 antagonistically regulate red light induced-programmed cell death in Arabidopsis. Front. Plant Sci. 2015, 6, 292. [CrossRef] [PubMed]

65. Kaminaka, H.; Näke, C.; Epple, P.; Dittgen, J.; Schütze, K.; Chaban, C.; Holt, B.F.; Merkle, T.; Schäfer, E.; Harter, K.; et al. bZIP10-LSD1 antagonism modulates basal defense and cell death in Arabidopsis following infection. EMBO J. 2006, 25, 4400-4411. [CrossRef] [PubMed]

66. Klopffleisch, K.; Phan, N.; Augustin, K.; Bayne, R.S.; Booker, K.S.; Botella, J.R.; Carpita, N.C.; Carr, T.; Chen, J.-G.; Cooke, T.R.; et al. Arabidopsis G-protein interactome reveals connections to cell wall carbohydrates and morphogenesis. Mol. Syst. Biol. 2011, 7, 532. [CrossRef] [PubMed]

67. Li, Y.; Chen, L.; Mu, J.; Zuo, J. LESION SIMULATING DISEASE1 interacts with catalases to regulate hypersensitive cell death in Arabidopsis. Plant Physiol. 2013, 163, 1059-1070. [CrossRef] [PubMed]

68. Trigg, S.A.; Garza, R.M.; MacWilliams, A.; Nery, J.R.; Bartlett, A.; Castanon, R.; Goubil, A.; Feeney, J.; O'Malley, R.; Huang, S.-S.C.; et al. CrY2H-seq: A massively multiplexed assay for deep-coverage interactome mapping. Nat. Methods 2017, 14, 819-825. [CrossRef] [PubMed]

69. Yoon, G.M.; Kieber, J.J. 14-3-3 regulates 1-aminocyclopropane-1-carboxylate synthase protein turnover in Arabidopsis. Plant Cell 2013, 25, 1016-1028. [CrossRef] [PubMed]

70. García, A.V.; Blanvillain-Baufumé, S.; Huibers, R.P.; Wiermer, M.; Li, G.; Gobbato, E.; Rietz, S.; Parker, J.E. Balanced nuclear and cytoplasmic activities of EDS1 are required for a complete plant innate immune response. PLOS Pathog. 2010, 6, e1000970. [CrossRef]

71. Zhu, S.; Jeong, R.D.; Venugopal, S.C.; Lapchyk, L.; Navarre, D.; Kachroo, A.; Kachroo, P. SAG101 forms a ternary complex with EDS1 and PAD4 and is required for resistance signaling against turnip crinkle virus. PLOS Pathog. 2011, 7, e1002318. [CrossRef]

72. Garcia-Molina, A.; Altmann, M.; Alkofer, A.; Epple, P.M.; Dangl, J.L.; Falter-Braun, P. LSU network hubs integrate abiotic and biotic stress responses via interaction with the superoxide dismutase FSD2. J. Exp. Bot. 2017, 68, 1185-1197. [CrossRef] 
73. Mohr, T.J.; Mammarella, N.D.; Hoff, T.; Woffenden, B.J.; Jelesko, J.G.; McDowell, J.M. The Arabidopsis downy mildew resistance gene RPP8 is induced by pathogens and salicylic acid and is regulated by $\mathrm{W}$ box cis elements. Mol. Plant-Microbe Interact. 2010, 23, 1303-1315. [CrossRef] [PubMed]

74. Zhang, X.C.; Gassmann, W. Alternative splicing and mRNA levels of the disease resistance gene RPS4 are induced during defense responses. Plant Physiol. 2007, 145, 1577-1587. [CrossRef] [PubMed]

75. Kim, Y.K.; Kim, S.; Shin, Y.; Hur, Y.S.; Kim, W.Y.; Lee, M.S.; Cheon, C.I.; Verma, D.P.S. Ribosomal protein $\mathrm{S} 6$, a target of rapamycin, is involved in the regulation of rRNA genes by possible epigenetic changes in Arabidopsis. J. Biol. Chem. 2014, 289, 3901-3912. [CrossRef] [PubMed]

76. Cai, Q.; Liang, C.; Wang, S.; Hou, Y.; Gao, L.; Liu, L.; He, W.; Ma, W.; Mo, B.; Chen, X. The disease resistance protein SNC1 represses the biogenesis of microRNAs and phased siRNAs. Nat. Commun. 2018, 9, 5080. [CrossRef] [PubMed]

77. Nguyen, P.D.T.; Pike, S.; Wang, J.; Nepal Poudel, A.; Heinz, R.; Schultz, J.C.; Koo, A.J.; Mitchum, M.G.; Appel, H.M.; Gassmann, W. The Arabidopsis immune regulator SRFR1 dampens defences against herbivory by Spodoptera exigua and parasitism by Heterodera schachtii. Mol. Plant Pathol. 2016, 17, 588-600. [CrossRef] [PubMed]

78. Gururani, M.A.; Venkatesh, J.; Tran, L.S.P. Regulation of photosynthesis during abiotic stress-induced photoinhibition. Mol. Plant 2015, 8, 1304-1320. [CrossRef]

79. Karpiński, S.; Szechyńska-Hebda, M. Secret life of plants: from memory to intelligence. Plant Signal. Behav. 2010, 5, 1391-1394. [CrossRef] [PubMed]

80. Szechyńska-Hebda, M.; Kruk, J.; Górecka, M.; Karpińska, B.; Karpiński, S. Evidence for light wavelength-specific photoelectrophysiological signaling and memory of excess light episodes in Arabidopsis. Plant Cell 2010, 22, 2201-2218. [CrossRef]

81. Apel, K.; Hirt, H. REACTIVE OXYGEN SPECIES: Metabolism, oxidative stress, and signal transduction. Annu. Rev. Plant Biol. 2004, 55, 373-399. [CrossRef]

82. Bailey-Serres, J.; Mittler, R. The roles of reactive oxygen species in plant cells. Plant Physiol. 2006, $141,311$. [CrossRef]

83. Bleecker, A.B.; Kende, H. Ethylene: A gaseous signal molecule in plants. Annu. Rev. Cell Dev. Biol. 2000, 16, 1-18. [CrossRef] [PubMed]

84. Dempsey, D.A.; Klessig, D.F. Salicylic acid, active oxygen species and systemic acquired resistance in plants. Trends Cell Biol. 1994, 4, 334-338. [CrossRef]

85. Lu, H.; Greenberg, J.T.; Holuigue, L. Editorial: Salicylic acid signaling networks. Front. Plant Sci. 2016, 7, 238. [CrossRef] [PubMed]

86. Mittler, R.; Vanderauwera, S.; Suzuki, N.; Miller, G.; Tognetti, V.B.; Vandepoele, K.; Gollery, M.; Shulaev, V.; Van Breusegem, F. ROS signaling: The new wave? Trends Plant Sci. 2011, 16, 300-309. [CrossRef] [PubMed]

87. Cui, H.; Gobbato, E.; Kracher, B.; Qiu, J.; Bautor, J.; Parker, J.E. A core function of EDS1 with PAD4 is to protect the salicylic acid defense sector in Arabidopsis immunity. New Phytol. 2017, 213, 1802-1817. [CrossRef]

88. Jordan, B.R. Review: Molecular response of plant cells to UV-B stress. Funct. Plant Biol. 2002, $29,909-916$. [CrossRef]

89. Khudyakova, A.Y.; Kreslavski, V.D.; Shirshikova, G.N.; Zharmukhamedov, S.K.; Kosobryukhov, A.A.; Allakhverdiev, S.I. Resistance of Arabidopsis thaliana L. photosynthetic apparatus to UV-B is reduced by deficit of phytochromes B and A. J. Photochem. Photobiol. B 2017, 169, 41-46. [CrossRef]

90. Cui, H.; Qiu, J.; Zhou, Y.; Bhandari, D.D.; Zhao, C.; Bautor, J.; Parker, J.E. Antagonism of transcription factor MYC2 by EDS1/PAD4 complexes bolsters salicylic acid defense in Arabidopsis effector-triggered immunity. Mol. Plant 2018, 11, 1053-1066. [CrossRef]

91. Khokon, M.A.R.; Okuma, E.; Hossain, M.A.; Munemasa, S.; Uraji, M.; Nakamura, Y.; Mori, I.C.; Murata, Y. Involvement of extracellular oxidative burst in salicylic acid-induced stomatal closure in Arabidopsis. Plant Cell Environ. 2011, 34, 434-443. [CrossRef]

92. Lawson, T.; Blatt, M.R. Stomatal size, speed, and responsiveness impact on photosynthesis and water use efficiency. Plant Physiol. 2014, 164, 1556-1570. [CrossRef]

93. Raven, J.A. Speedy small stomata? J. Exp. Bot. 2014, 65, 1415-1424. [CrossRef] [PubMed]

94. Devireddy, A.R.; Zandalinas, S.I.; Gómez-Cadenas, A.; Blumwald, E.; Mittler, R. Coordinating the overall stomatal response of plants: Rapid leaf-to-leaf communication during light stress. Sci Signal 2018, 11, eaam9514. [CrossRef] [PubMed] 
95. Dat, J.; Vandenabeele, S.; Vranová, E.; Montagu, M.V.; Inzé, D.; Breusegem, F.V. Dual action of the active oxygen species during plant stress responses. Cell. Mol. Life Sci. 2000, 57, 779-795. [CrossRef] [PubMed]

96. Breusegem, F.V.; Dat, J.F. Reactive oxygen species in plant cell death. Plant Physiol. 2006, 141, $384-390$. [CrossRef] [PubMed]

97. Murata, N.; Takahashi, S.; Nishiyama, Y.; Allakhverdiev, S.I. Photoinhibition of photosystem II under environmental stress. Biochim. Biophys. Acta BBA Bioenerg. 2007, 1767, 414-421. [CrossRef] [PubMed]

98. Czarnocka, W.; Karpiński, S. Friend or foe? Reactive oxygen species production, scavenging and signaling in plant response to environmental stresses. Free Radic. Biol. Med. 2018, 122, 4-20. [CrossRef] [PubMed]

99. Choudhury, F.K.; Rivero, R.M.; Blumwald, E.; Mittler, R. Reactive oxygen species, abiotic stress and stress combination. Plant J. 2017, 90, 856-867. [CrossRef]

100. Gilroy, S.; Białasek, M.; Suzuki, N.; Górecka, M.; Devireddy, A.R.; Karpiński, S.; Mittler, R. ROS, Calcium, and Electric Signals: Key Mediators of Rapid Systemic Signaling in Plants. Plant Physiol. 2016, 171, 1606-1615. [CrossRef]

101. Lee, K.P.; Kim, C.; Landgraf, F.; Apel, K. EXECUTER1- and EXECUTER2-dependent transfer of stress-related signals from the plastid to the nucleus of Arabidopsis thaliana. Proc. Natl. Acad. Sci. 2007, 104, 10270-10275. [CrossRef]

102. Queval, G.; Issakidis-Bourguet, E.; Hoeberichts, F.A.; Vandorpe, M.; Gakière, B.; Vanacker, H.; Miginiac-Maslow, M.; Breusegem, F.V.; Noctor, G. Conditional oxidative stress responses in the Arabidopsis photorespiratory mutant cat 2 demonstrate that redox state is a key modulator of daylength-dependent gene expression, and define photoperiod as a crucial factor in the regulation of $\mathrm{H}_{2} \mathrm{O}_{2}$-induced cell death. Plant J. 2007, 52, 640-657.

103. Vandenabeele, S.; Vanderauwera, S.; Vuylsteke, M.; Rombauts, S.; Langebartels, C.; Seidlitz, H.K.; Zabeau, M.; Van Montagu, M.; Inzé, D.; Van Breusegem, F. Catalase deficiency drastically affects gene expression induced by high light in Arabidopsis thaliana. Plant J. 2004, 39, 45-58. [CrossRef] [PubMed]

104. Catinot, J.; Buchala, A.; Abou-Mansour, E.; Métraux, J.-P. Salicylic acid production in response to biotic and abiotic stress depends on isochorismate in Nicotiana benthamiana. FEBS Lett. 2008, 582, 473-478. [CrossRef] [PubMed]

105. Lawton, K.A.; Friedrich, L.; Hunt, M.; Weymann, K.; Delaney, T.; Kessmann, H.; Staub, T.; Ryals, J. Benzothiadiazole induces disease resistance in Arabidopsis by activation of the systemic acquired resistance signal transduction pathway. Plant J. Cell Mol. Biol. 1996, 10, 71-82. [CrossRef]

106. Abreu, M.E.; Munné-Bosch, S. Salicylic acid deficiency in NahG transgenic lines and sid2 mutants increases seed yield in the annual plant Arabidopsis thaliana. J. Exp. Bot. 2009, 60, 1261-1271. [CrossRef] [PubMed]

107. Witoń, D.; Gawroński, P.; Czarnocka, W.;Ślesak, I.; Rusaczonek, A.; Sujkowska-Rybkowska, M.; Bernacki, M.J.; Dąbrowska-Bronk, J.; Tomsia, N.; Szechyńska-Hebda, M.; et al. Mitogen activated protein kinase 4 (MPK4) influences growth in Populus tremula L. $\times$ tremuloides. Environ. Exp. Bot. 2016, 130, 189-205. [CrossRef]

108. Iglesias, M.J.; Terrile, M.C.; Casalongué, C.A. Auxin and salicylic acid signalings counteract the regulation of adaptive responses to stress. Plant Signal. Behav. 2011, 6, 452-454. [CrossRef] [PubMed]

109. Klessig, D.F.; Choi, H.W.; Dempsey, D.A. Systemic acquired resistance and salicylic acid: Past, present, and future. Mol. Plant. Microbe Interact. 2018, 31, 871-888. [CrossRef] [PubMed]

110. Wang, D.; Pajerowska-Mukhtar, K.; Culler, A.H.; Dong, X. Salicylic acid inhibits pathogen growth in plants through repression of the auxin signaling pathway. Curr. Biol. 2007, 17, 1784-1790. [CrossRef]

111. Jirage, D.; Zhou, N.; Cooper, B.; Clarke, J.D.; Dong, X.; Glazebrook, J. Constitutive salicylic acid-dependent signaling in cpr1 and cpr6 mutants requires PAD4. Plant J. 2001, 26, 395-407. [CrossRef]

112. Rate, D.N.; Cuenca, J.V.; Bowman, G.R.; Guttman, D.S.; Greenberg, J.T. The gain-of-function Arabidopsis acd6 mutant reveals novel regulation and function of the salicylic acid signaling pathway in controlling cell death, defenses, and cell growth. Plant Cell 1999, 11, 1695-1708. [CrossRef]

113. Makandar, R.; Nalam, V.J.; Chowdhury, Z.; Sarowar, S.; Klossner, G.; Lee, H.; Burdan, D.; Trick, H.N.; Gobbato, E.; Parker, J.E.; et al. The combined action of ENHANCED DISEASE SUSCEPTIBILITY1, PHYTOALEXIN DEFICIENT4, and SENESCENCE-ASSOCIATED101 promotes salicylic acid-mediated defenses to limit Fusarium graminearum infection in Arabidopsis thaliana. Mol. Plant Microbe Interact. 2015, 28, 943-953. [CrossRef] [PubMed]

114. Gutiérrez-Coronado, M.A.; Trejo-López, C.; Larqué-Saavedra, A. Effects of salicylic acid on the growth of roots and shoots in soybean. Plant Physiol. Biochem. 1998, 36, 563-565. [CrossRef] 
115. Shakirova, F.M.; Sakhabutdinova, A.R.; Bezrukova, M.V.; Fatkhutdinova, R.A.; Fatkhutdinova, D.R. Changes in the hormonal status of wheat seedlings induced by salicylic acid and salinity. Plant Sci. 2003, 164, 317-322. [CrossRef]

116. Singh, B.; Usha, K. Salicylic acid induced physiological and biochemical changes in wheat seedlings under water stress. Plant Growth Regul. 2003, 39, 137-141. [CrossRef]

117. Gunes, A.; Inal, A.; Alpaslan, M.; Eraslan, F.; Bagci, E.G.; Cicek, N. Salicylic acid induced changes on some physiological parameters symptomatic for oxidative stress and mineral nutrition in maize (Zea mays L.) grown under salinity. J. Plant Physiol. 2007, 164, 728-736. [CrossRef] [PubMed]

118. Kovácik, J.; Grúz, J.; Backor, M.; Strnad, M.; Repcák, M. Salicylic acid-induced changes to growth and phenolic metabolism in Matricaria chamomilla plants. Plant Cell Rep. 2009, 28, 135-143. [CrossRef] [PubMed]

119. Scott, I.M.; Clarke, S.M.; Wood, J.E.; Mur, L.A. Salicylate accumulation inhibits growth at chilling temperature in Arabidopsis. Plant Physiol. 2004, 135, 1040-1049. [CrossRef] [PubMed]

120. Gawroński, P.; Witoń, D.; Vashutina, K.; Bederska, M.; Betliński, B.; Rusaczonek, A.; Karpiński, S. Mitogen-activated protein kinase 4 is a salicylic acid-independent regulator of growth but not of photosynthesis in Arabidopsis. Mol. Plant 2014, 7, 1151-1166. [CrossRef]

121. Ślesak, I.; Szechyńska-Hebda, M.; Fedak, H.; Sidoruk, N.; Dąbrowska-Bronk, J.; Witoń, D.; Rusaczonek, A.; Antczak, A.; Drożdżek, M.; Karpińska, B.; et al. PHYTOALEXIN DEFICIENT 4 affects reactive oxygen species metabolism, cell wall and wood properties in hybrid aspen (Populus tremula L. $\times$ tremuloides). Plant Cell Environ. 2015, 38, 1275-1284. [CrossRef]

122. Wrzaczek, M.; Brosché, M.; Kangasjärvi, J. ROS signaling loops - production, perception, regulation. Curr. Opin. Plant Biol. 2013, 16, 575-582. [CrossRef]

123. Ecker, J.R. The ethylene signal transduction pathway in plants. Science 1995, 268, 667-675. [CrossRef] [PubMed]

124. Guo, H.; Ecker, J.R. The ethylene signaling pathway: new insights. Curr. Opin. Plant Biol. 2004, 7, 40-49. [CrossRef] [PubMed]

125. Vaseva, I.I.; Qudeimat, E.; Potuschak, T.; Du, Y.; Genschik, P.; Vandenbussche, F.; Straeten, D.V.D. The plant hormone ethylene restricts Arabidopsis growth via the epidermis. Proc. Natl. Acad. Sci. 2018, 115, E4130-E4139. [CrossRef] [PubMed]

126. Kieber, J.J.; Rothenberg, M.; Roman, G.; Feldmann, K.A.; Ecker, J.R. CTR1, a negative regulator of the ethylene response pathway in Arabidopsis, encodes a member of the raf family of protein kinases. Cell 1993, 72, 427-441. [CrossRef]

127. Rodrigues-Pousada, R.A.; De Rycke, R.; Dedonder, A.; Van Caeneghem, W.; Engler, G.; Van Montagu, M.; Van Der Straeten, D. The Arabidopsis 1-aminocyclopropane-1-carboxylate synthase gene 1 is expressed during early development. Plant Cell 1993, 5, 897-911. [CrossRef] [PubMed]

128. Farwell, A.J.; Vesely, S.; Nero, V.; Rodriguez, H.; Shah, S.; Dixon, D.G.; Glick, B.R. The use of transgenic canola (Brassica napus) and plant growth-promoting bacteria to enhance plant biomass at a nickel-contaminated field site. Plant Soil 2006, 288, 309-318. [CrossRef]

129. Wituszyńska, W.; Karpiński, S. Programmed cell death as a response to high light, UV and drought stress in plants. In Abiotic Stress-Plant Responses and Applications in Agriculture; InTech: Rijeka, Croatia, 2013; pp. 207-246. ISBN 978-953-51-1024-8.

130. Mullineaux, P.; Karpinski, S. Signal transduction in response to excess light: getting out of the chloroplast. Curr. Opin. Plant Biol. 2002, 5, 43-48. [CrossRef]

131. Szechyńska-Hebda, M.; Lewandowska, M.; Karpiński, S. Electrical signaling, photosynthesis and systemic acquired acclimation. Front. Physiol. 2017, 14, 684. [CrossRef]

132. Karpiński, S.; Szechyńska-Hebda, M. Cellular light memory, photo-electrochemical and redox retrograde signaling in plants. BioTechnologia 2014, 93, 27-39. [CrossRef]

133. Wituszynska, W.; Karpinski, S. Determination of Water Use Efficiency for Arabidopsis thaliana. BIO-Protoc. 2014, 4. [CrossRef]

134. Foyer, C.H.; Neukermans, J.; Queval, G.; Noctor, G.; Harbinson, J. Photosynthetic control of electron transport and the regulation of gene expression. J. Exp. Bot. 2012, 63, 1637-1661. [CrossRef] [PubMed]

135. Karpinski, S.; Escobar, C.; Karpinska, B.; Creissen, G.; Mullineaux, P.M. Photosynthetic electron transport regulates the expression of cytosolic ascorbate peroxidase genes in Arabidopsis during excess light stress. Plant Cell 1997, 9, 627-640. [PubMed] 
136. Lee, S.; Choi, H.; Suh, S.; Doo, I.S.; Oh, K.Y.; Choi, E.J.; Taylor, A.T.S.; Low, P.S.; Lee, Y. Oligogalacturonic acid and chitosan reduce stomatal aperture by inducing the evolution of reactive oxygen species from guard cells of tomato and commelina communis. Plant Physiol. 1999, 121, 147-152. [CrossRef] [PubMed]

137. Miura, K.; Okamoto, H.; Okuma, E.; Shiba, H.; Kamada, H.; Hasegawa, P.M.; Murata, Y. SIZ1 deficiency causes reduced stomatal aperture and enhanced drought tolerance via controlling salicylic acid-induced accumulation of reactive oxygen species in Arabidopsis. Plant J. Cell Mol. Biol. 2013, 73, 91-104. [CrossRef] [PubMed]

138. Taylor, G. Populus: Arabidopsis for forestry. Do we need a model tree? Ann. Bot. 2002, 90, 681-689. [CrossRef] [PubMed]

139. Christersson, L. Poplar plantations for paper and energy in the south of Sweden. Biomass Bioenergy 2008, 32, 997-1000. [CrossRef]

140. Devappa, R.K.; Rakshit, S.K.; Dekker, R.F.H. Potential of poplar bark phytochemicals as value-added co-products from the wood and cellulosic bioethanol industry. BioEnergy Res. 2015, 8, 1235-1251. [CrossRef]

141. Barigah, T.S.; Saugier, B.; Mousseau, M.; Guittet, J.; Ceulemans, R. Photosynthesis, leaf area and productivity of 5 poplar clones during their establishment year. Ann. Sci. For. 1994, 51, 613-625. [CrossRef]

142. Koch, J.R.; Creelman, R.A.; Eshita, S.M.; Seskar, M.; Mullet, J.E.; Davis, K.R. Ozone Sensitivity in Hybrid Poplar Correlates with Insensitivity to Both Salicylic Acid and Jasmonic Acid. The Role of Programmed Cell Death in Lesion Formation. Plant Physiol. 2000, 123, 487-496. [CrossRef]

143. Matte Risopatron, J.P.; Sun, Y.; Jones, B.J. The vascular cambium: molecular control of cellular structure. Protoplasma 2010, 247, 145-161. [CrossRef]

144. Gonzalez, N.; Beemster, G.T.; Inzé, D. David and Goliath: What can the tiny weed Arabidopsis teach us to improve biomass production in crops? Curr. Opin. Plant Biol. 2009, 12, 157-164. [CrossRef] [PubMed]

145. Jones, B.; Wang, J.; Sandberg, G. Methods of Increasing Plant Growth 2008. Available online: https: //patentscope.wipo.int/search/en/detail.jsf?docId=WO2008125983 (accessed on 20 April 2019).

146. Kim, J.H.; Choi, D.; Kende, H. The AtGRF family of putative transcription factors is involved in leaf and cotyledon growth in Arabidopsis. Plant J. Cell Mol. Biol. 2003, 36, 94-104. [CrossRef]

147. Mizukami, Y.; Fischer, R.L. Plant organ size control: AINTEGUMENTA regulates growth and cell numbers during organogenesis. Proc. Natl. Acad. Sci. 2000, 97, 942-947. [CrossRef] [PubMed]

148. Beemster, G.T.S.; Fiorani, F.; Inzé, D. Cell cycle: the key to plant growth control? Trends Plant Sci. 2003, 8, 154-158. [CrossRef]

149. Eriksson, M.E.; Israelsson, M.; Olsson, O.; Moritz, T. Increased gibberellin biosynthesis in transgenic trees promotes growth, biomass production and xylem fiber length. Nat. Biotechnol. 2000, 18, 784-788. [CrossRef] [PubMed]

150. Werner, T.; Motyka, V.; Strnad, M.; Schmülling, T. Regulation of plant growth by cytokinin. Proc. Natl. Acad. Sci. USA 2001, 98, 10487-10492. [CrossRef] [PubMed]

151. Abramson, M.; Shoseyov, O.; Shani, Z. Plant cell wall reconstruction toward improved lignocellulosic production and processability. Plant Sci. 2010, 178, 61-72. [CrossRef]

152. Foreman, J.; Demidchik, V.; Bothwell, J.H.F.; Mylona, P.; Miedema, H.; Torres, M.A.; Linstead, P.; Costa, S.; Brownlee, C.; Jones, J.D.G.; et al. Reactive oxygen species produced by NADPH oxidase regulate plant cell growth. Nature 2003, 422, 442-446. [CrossRef]

153. Barros, J.; Escamilla-Trevino, L.; Song, L.; Rao, X.; Serrani-Yarce, J.C.; Palacios, M.D.; Engle, N.; Choudhury, F.K.; Tschaplinski, T.J.; Venables, B.J.; et al. 4-Coumarate 3-hydroxylase in the lignin biosynthesis pathway is a cytosolic ascorbate peroxidase. Nat Commun. 2019, 30, 1994. [CrossRef]

154. O’Brien, J.A.; Daudi, A.; Finch, P.; Butt, V.S.; Whitelegge, J.P.; Souda, P.; Ausubel, F.M.; Bolwell, G.P. A peroxidase-dependent apoplastic oxidative burst in cultured Arabidopsis cells functions in MAMP-elicited defense. Plant Physiol. 2012, 158, 2013-2027. [CrossRef]

155. Potikha, T.S.; Collins, C.C.; Johnson, D.I.; Delmer, D.P.; Levine, A. The involvement of hydrogen peroxide in the differentiation of secondary walls in cotton fibers. Plant Physiol. 1999, 119, 849-858. [CrossRef] [PubMed]

156. Ros Barceló, A. Xylem parenchyma cells deliver the $\mathrm{H}_{2} \mathrm{O}_{2}$ necessary for lignification in differentiating xylem vessels. Planta 2005, 220, 747-756. [CrossRef] [PubMed]

157. Gallego-Giraldo, L.; Escamilla-Trevino, L.; Jackson, L.A.; Dixon, R.A. Salicylic acid mediates the reduced growth of lignin down-regulated plants. Proc. Natl. Acad. Sci. USA 2011, 108, 20814-20819. [CrossRef] [PubMed] 
158. Madadi, M.; Penga, C.; and Abbas, A. Advances in genetic manipulation of lignocellulose to reduce biomass recalcitrance and enhance biofuel production in bioenergy crops. Plant Biochem. Physiol. 2017, 5, 2.

159. Montgomery, R. Relative importance of photosynthetic physiology and biomass allocation for tree seedling growth across a broad light gradient. Tree Physiol. 2004, 24, 155-167. [CrossRef] [PubMed]

160. Humphry, M.; Bednarek, P.; Kemmerling, B.; Koh, S.; Stein, M.; Göbel, U.; Stüber, K.; Piślewska-Bednarek, M.; Loraine, A.; Schulze-Lefert, P.; et al. A regulon conserved in monocot and dicot plants defines a functional module in antifungal plant immunity. Proc. Natl. Acad. Sci. USA 2010, 107, 21896-21901. [CrossRef] [PubMed]

161. Wing, R.A.; Purugganan, M.D.; Zhang, Q. The rice genome revolution: from an ancient grain to Green Super Rice. Nat. Rev. Genet. 2018, 19, 05-517. [CrossRef]

162. Muthayya, S.; Sugimoto, J.D.; Montgomery, S.; Maberly, G.F. An overview of global rice production, supply, trade, and consumption. Ann. N. Y. Acad. Sci. 2014, 1324, 7-14. [CrossRef]

163. Jackson, S.A. Rice: The first crop genome. Rice 2016, 9, 14. [CrossRef]

164. Huang, L.; Zhang, H.; Hong, Y.; Liu, S.; Li, D.; Song, F. Stress-responsive expression, subcellular localization and protein-protein interactions of the rice metacaspase family. Int. J. Mol. Sci. 2015, 16, 16216-16241. [CrossRef]

165. Chen, S.; Li, X.; Lavoie, M.; Jin, Y.; Xu, J.; Fu, Z.; Qian, H. Diclofop-methyl affects microbial rhizosphere community and induces systemic acquired resistance in rice. J. Environ. Sci. 2017, 51, 352-360. [CrossRef]

166. Duan, C.; Yu, J.; Bai, J.; Zhu, Z.; Wang, X. Induced defense responses in rice plants against small brown planthopper infestation. Crop J. 2014, 2, 55-62. [CrossRef]

167. Feys, B.J.; Wiermer, M.; Bhat, R.A.; Moisan, L.J.; Medina-Escobar, N.; Neu, C.; Cabral, A.; Parker, J.E. Arabidopsis SENESCENCE-ASSOCIATED GENE101 stabilizes and signals within an ENHANCED DISEASE SUSCEPTIBILITY1 complex in plant innate immunity. Plant Cell 2005, 17, 2601-2613. [CrossRef] [PubMed]

168. Alagumani, T.; Anjugam, M. Economic analysis of grape production in Tamil Nadu. J. Innov. Agric. 2018, 5, $13-18$.

169. Jiao, L.; Zhang, Y.; Lu, J. Overexpression of a stress-responsive U-box protein gene VaPUB affects the accumulation of resistance related proteins in Vitis vinifera 'Thompson Seedless'. Plant Physiol. Biochem. 2017, 112, 53-63. [CrossRef]

170. Mutawila, C.; Stander, C.; Halleen, F.; Vivier, M.A.; Mostert, L. Response of Vitis vinifera cell cultures to Eutypa lata and Trichoderma atroviride culture filtrates: Expression of defence-related genes and phenotypes. Protoplasma 2017, 254, 863-879. [CrossRef] [PubMed]

171. Stempien, E.; Goddard, M.L.; Leva, Y.; Bénard-Gellon, M.; Laloue, H.; Farine, S.; Kieffer-Mazet, F.; Tarnus, C.; Bertsch, C.; Chong, J. Secreted proteins produced by fungi associated with Botryosphaeria dieback trigger distinct defense responses in Vitis vinifera and Vitis rupestris cells. Protoplasma 2018, 255, 613-628. [CrossRef]

172. Zaini, P.A.; Nascimento, R.; Gouran, H.; Cantu, D.; Chakraborty, S.; Phu, M.; Goulart, L.R.; Dandekar, A.M. Molecular profiling of pierce's disease outlines the response circuitry of Vitis vinifera to Xylella fastidiosa infection. Front. Plant Sci. 2018, 9. [CrossRef]

173. Zhang, N.; Li, R.; Shen, W.; Jiao, S.; Zhang, J.; Xu, W. Genome-wide evolutionary characterization and expression analyses of major latex protein (MLP) family genes in Vitis vinifera. Mol. Genet. Genomics 2018, 293, 1061-1075. [CrossRef]

174. Islam, M.Z.; Yun, H.K. Three transcripts of EDS1-like genes respond differently to Vitis flexuosa infection. J. Plant Biotechnol. 2017, 44, 125-134. [CrossRef]

175. Tandon, G.; Jaiswal, S.; Iquebal, M.A.; Kumar, S.; Kaur, S.; Rai, A.; Kumar, D. Evidence of salicylic acid pathway with EDS1 and PAD4 proteins by molecular dynamics simulation for grape improvement. J. Biomol. Struct. Dyn. 2015, 33, 2180-2191. [CrossRef] [PubMed]

176. Sunilkumar, G.; Campbell, L.M.; Puckhaber, L.; Stipanovic, R.D.; Rathore, K.S. Engineering cottonseed for use in human nutrition by tissue-specific reduction of toxic gossypol. Proc. Natl. Acad. Sci. 2006, 103, 18054-18059. [CrossRef] [PubMed]

177. Bejarano-Alcázar, J.; Blanco-López, M.A.; Melero-Vara, J.M.; Jiménez-Díaz, R.M. The influence of verticillium wilt epidemics on cotton yield in southern Spain. Plant Pathol. 1997, 46, 168-178. [CrossRef]

178. Zhang, B.; Yang, Y.; Chen, T.; Yu, W.; Liu, T.; Li, H.; Fan, X.; Ren, Y.; Shen, D.; Liu, L.; et al. Island cotton Gbve1 gene encoding a receptor-like protein confers resistance to both defoliating and non-defoliating isolates of Verticillium dahliae. PloS ONE 2012, 7, e51091. [CrossRef] [PubMed] 
179. Greenhalf, W.; Stephan, C.; Chaudhuri, B. Role of mitochondria and C-terminal membrane anchor of Bcl-2 in Bax induced growth arrest and mortality in Saccharomyces cerevisiae. FEBS Lett. 1996, 380, 169-175. [CrossRef]

180. Kawai-Yamada, M.; Jin, L.; Yoshinaga, K.; Hirata, A.; Uchimiya, H. Mammalian bax-induced plant cell death can be down-regulated by overexpression of Arabidopsis Bax Inhibitor-1 (AtBI-1). Proc. Natl. Acad. Sci. USA 2001, 98, 12295-12300. [CrossRef] [PubMed]

181. Lacomme, C.; Cruz, S.S. Bax-induced cell death in tobacco is similar to the hypersensitive response. Proc. Natl. Acad. Sci. 1999, 96, 7956-7961. [CrossRef]

182. Pajerowska, K.M.; Parker, J.E.; Gebhardt, C. Potato homologs of Arabidopsis thaliana genes functional in defense signaling-identification, genetic mapping, and molecular cloning. Mol. Plant. Microbe Interact. 2005, 18, 1107-1119. [CrossRef]

183. Pant, S.R.; Krishnavajhala, A.; McNeece, B.T.; Lawrence, G.W.; Klink, V.P. The syntaxin 31-induced gene, LESION SIMULATING DISEASE1 (LSD1), functions in Glycine max defense to the root parasite Heterodera glycines. Plant Signal. Behav. 2015, 10, e977737. [CrossRef]

184. Sharma, S.; Jaiswal, S.; Archak, S. Annotation of gene sequence and protein structure of brinjal EDS1. Bioinformation 2017, 13, 54-59. [CrossRef]

185. Heidrich, K.; Wirthmueller, L.; Tasset, C.; Pouzet, C.; Deslandes, L.; Parker, J.E. Arabidopsis EDS1 connects pathogen effector recognition to cell compartment-specific immune responses. Science 2011, 334, 1401-1404. [CrossRef] [PubMed]

186. Veluchamy, S.; Panthee, D.R. Differential expression analysis of a select list of genes in susceptible and resistant heirloom tomatoes with respect. Eur. J. Plant Pathol. 2015, 142, 653-663. [CrossRef]

187. Singh, V.; Shah, J. Tomato responds to green peach aphid infestation with the activation of trehalose metabolism and starch accumulation. Plant Signal. Behav. 2012, 7, 605-607. [CrossRef] [PubMed]

188. Wang, J.; Shine, M.B.; Gao, Q.M.; Navarre, D.; Jiang, W.; Liu, C.; Chen, Q.; Hu, G.; Kachroo, A. Enhanced disease susceptibility1 mediates pathogen resistance and virulence function of a bacterial effector in soybean. Plant Physiol. 2014, 165, 1269-1284. [CrossRef] [PubMed]

(C) 2019 by the authors. Licensee MDPI, Basel, Switzerland. This article is an open access article distributed under the terms and conditions of the Creative Commons Attribution (CC BY) license (http://creativecommons.org/licenses/by/4.0/). 